\title{
Degradation of Organic Contaminants by Advanced Electrochemical Oxidation Methods
}

\author{
E. Brillas*, C. Arias, P.-L. Cabot, F. Centellas, J.A. Garrido, R.M. Rodríguez \\ Laboratori de Ciència i Tecnologia Electroquímica de Materials (LCTEM), Departament de \\ Química Física, Facultat de Química, Universitat de Barcelona, Martí i Franquès 1-11, 08028 \\ Barcelona, Spain
}

Received 9 September 2005

\begin{abstract}
Advanced electrochemical oxidation processes (AEOPs) constitute promising technologies for the treatment of organic pollutants in waters. They are based on the production of oxidant hydroxyl radical $\left({ }^{\circ} \mathrm{OH}\right)$ from water oxidation on the surface of a high $\mathrm{O}_{2}$-overvoltage anode and/or from Fenton's reaction between added $\mathrm{Fe}^{2+}$ and hydrogen peroxide electrogenerated at the cathode by two-electron $\mathrm{O}_{2}$ reduction. In this paper, fundamentals of AEOPs such as anodic oxidation, electro-Fenton, photoelectroFenton and peroxi-coagulation are described, and comparative degradation of aqueous solutions with aromatic pollutants, such as aniline, 4-chlorophenol and several chlorophenoxyacetic and chlorobenzoic acids, in $0.05 \mathrm{M} \mathrm{Na}_{2} \mathrm{SO}_{4}+\mathrm{H}_{2} \mathrm{SO}_{4}$ of $\mathrm{pH} 3.0$ by these techniques using an undivided electrolytic cell with an $\mathrm{O}_{2}$-diffusion cathode under galvanostatic conditions is discussed. The decay kinetics of chlorophenoxyacetic acids and the evolution of their aromatic intermediates and generated carboxylic acids are also reported to clarify their mineralization processes by the different AEOPs. Anodic oxidation with a Pt anode yields poor decontamination of pollutants, while alternative anodic oxidation with a boron-doped diamond (BDD) anode leads to total mineralization of all solutions due to the greater production of ${ }^{\circ} \mathrm{OH}$ on the BDD surface. Electro-Fenton with a Pt anode has high oxidation ability at short electrolysis times, but the formation of stable $\mathrm{Fe}^{3+}$-oxalate complexes limits the degradation of aromatic contaminants. These products are completely oxidized in electro-Fenton with a BDD anode or photodecomposed by the action of UVA light in photoelectro-Fenton with a Pt anode. Peroxi-coagulation with an $\mathrm{Fe}$ anode also gives fast degradation with generation of small amounts of stable $\mathrm{Fe}^{3+}$ complexes, since organics are mainly retained in the $\mathrm{Fe}(\mathrm{OH})_{3}$ precipitate formed.
\end{abstract}

Keywords: anodic oxidation, boron-doped diamond electrode, electro-Fenton, photoelectro-Fenton, peroxi-coagulation.

\footnotetext{
* Corresponding author. E-mail address: brillas@ub.edu.
} 


\section{Introduction}

A large variety of commercial organics such as herbicides, pesticides, dyes, drugs, etc., are found as common contaminants of the aquatic environment. This pollution is due to the widespread use of thousands of tons of these compounds in domestic, industrial and agricultural activities, especially in developed countries, generating great amounts of contaminated wastewaters, whose direct disposal to natural channels causes their accumulation in the environment. Although very small levels of much commercial organics, usually $<10 \mu \mathrm{g} \mathrm{L}^{-1}[1$ 3], are detected in surface and ground waters, most of them are hardly biodegradable and toxic for humans and animals. The need of avoiding the adverse effects of soluble pollutants on the health of living organisms makes necessary the purification of natural and drinking waters to restore their quality. Industrial wastewaters with high organics contents have also to be directly decontaminated for their reuse in human activities.

In the last decade, an increasing number of procedures to remove organics from aqueous media have been reported. Among these techniques, the so-called advanced oxidation processes (AOPs) have received great attention because they can provide an efficient degradation of most soluble contaminants [4]. AOPs are environmentally friendly methods based on the chemical, photochemical, photocatalytical or electrochemical production of hydroxyl radical $\left({ }^{\circ} \mathrm{OH}\right)$, which is the second species known after fluorine with higher oxidation power in acidic media, having a standard potential of $2.80 \mathrm{~V}$ vs. NHE [5]. This radical acts as a non-selective, very strong oxidant agent with ability to react with organics giving dehydrogenated or hydroxylated derivatives, until achieving their total mineralization, i.e. their conversion into $\mathrm{CO}_{2}$, water and inorganic ions. However, some of the simplest organic molecules such as acetic, maleic and oxalic acids are not oxidized in solution by ${ }^{\circ} \mathrm{OH}$ produced by chemical methods [6]. These species can be effectively destroyed by alternative electrochemical procedures, the so-called advanced electrochemical oxidation processes (AEOPs), which are powerful emergent technologies for water remediation.

This paper is focused to revise the application of AEOPs to the degradation of organic pollutants in waters. Fundamentals of AEOPs such as anodic oxidation and different indirect electrooxidation techniques based on $\mathrm{H}_{2} \mathrm{O}_{2}$ electrogeneration, as electro-Fenton, photoelectro-Fenton and peroxicoagulation, are initially described. Comparative treatment of acidic aqueous solutions of aniline, 4-chlorophenol and chlorophenoxyacetic and chlorobenzoic acids herbicides by such AEOPs using an undivided electrolytic cell with an $\mathrm{O}_{2}$ diffusion cathode is further presented to analyze the degradation characteristics and oxidation power of each method.

\section{Fundamentals of AEOPs}

Anodic oxidation

Direct anodic oxidation is the most popular electrochemical method to remove organics pollutants from water streams or reservoirs [7-40]. This is feasible by 
reaction of organics with adsorbed hydroxyl radical $\left({ }^{\circ} \mathrm{OH}_{\mathrm{ads}}\right)$ formed at the anode surface from water oxidation:

$$
\mathrm{H}_{2} \mathrm{O} \rightarrow{ }^{\bullet} \mathrm{OH}_{\mathrm{ads}}+\mathrm{H}^{+}+\mathrm{e}^{-}
$$

In anodic oxidation contaminated solutions are usually treated in the anodic compartment of a divided cell with conventional anodes such as $\mathrm{Pt}$ [7-14], $\mathrm{IrO}_{2}$ [14,22], $\mathrm{RuO}_{2}$ [16], doped $\mathrm{SnO}_{2}$ [8,9,17,18] and undoped and doped $\mathrm{PbO}_{2}$ $[7,15,23]$. When low cell voltages avoiding $\mathrm{O}_{2}$ evolution are applied, the activity of such anodes decreases with time because of the adsorption of poisoning species on their surface. These species can only be oxidized by ${ }^{\bullet} \mathrm{OH}$ generated at high anodic potentials in the region of water discharge with simultaneous $\mathrm{O}_{2}$ evolution, thus producing regeneration of the anode surface. Unfortunately, the above anodes yield slow mineralization of most aromatic solutions due to the generation, in more or less extent, of short carboxylic acids that hardly react with OH. Recent studies have shown that these products can be rapidly destroyed by a boron-doped diamond (BDD) thin film anode with greater $\mathrm{O}_{2}$-overvoltage that allows the production of higher amounts of ${ }^{\bullet} \mathrm{OH}$ with ability to react with organics adsorbed on its surface. Anodic oxidation with BDD seems an adequate method for achieving the total mineralization of organic pollutants, as found for $\mathrm{HClO}_{4}$ solutions with carboxylic acids such as acetic, formic and oxalic [24], 4chlorophenol [25], phenol [26], benzoic acid [27] and herbicide 4chlorophenoxyacetic acid [28], as well as for aqueous solutions with phenol wastes [29], malic and ethylenediaminetetraacetic acids [30], amarantha dyestuff [31], formic, oxalic and maleic acids [32], chlorophenoxyacetic acid herbicides [33], diuron and 3,4-dichloroaniline [34], 2-naphtol [35], 4-nitrophenol [36], oxalic acid [37], 2,4-dinitrophenol [38], 4,6-dinitro-o-cresol [39] and paracetamol [40].

Two extreme approaches have then been established to explain the pollution abatement in waters by anodic oxidation [16]:

(i) the electrochemical conversion method, in which refractory organics are selectively transformed into biodegradable compounds, usually carboxylic acids;

(ii) the electrochemical combustion (or electrochemical incineration) method, in which organics are completely mineralized.

In both cases relatively high cell voltages are utilized to produce the simultaneous anodic oxidation of pollutants and water. Experimental results reveal that several anodes such as $\mathrm{Pt}$ [7-14], $\mathrm{IrO}_{2}$ [14,22] and $\mathrm{RuO}_{2}$ [16], favor the electrochemical conversion with low current efficiency, while others such as doped $\mathrm{SnO}_{2}[8,9,17,18]$, undoped and doped $\mathrm{PbO}_{2}$ [7,15,23] and $\mathrm{BDD}$ [24-40], allow the electrochemical combustion with higher current efficiency. To explain this different behavior, Comninellis and De Battisti [16] have proposed a simple mechanism when the anode surface is formed by a metallic oxide $\mathrm{MO}_{\mathrm{x}}$. The oxidation process is initiated by the discharge of $\mathrm{H}_{2} \mathrm{O}$ in acid solution (or $\mathrm{OH}^{-}$in alkaline medium) at the anode to yield adsorbed hydroxyl radical by reaction (2), 
which can further undergo an oxygen transfer to the lattice of the metallic oxide giving the so-called higher metallic oxide $\mathrm{MO}_{\mathrm{x}+1}$ by reaction (3).

$$
\begin{aligned}
& \mathrm{MO}_{\mathrm{x}}+\mathrm{H}_{2} \mathrm{O} \rightarrow \mathrm{MO}_{\mathrm{x}}\left({ }^{\circ} \mathrm{OH}\right)+\mathrm{H}^{+}+\mathrm{e}^{-} \\
& \mathrm{MO}_{\mathrm{x}}\left({ }^{\bullet} \mathrm{OH}\right) \rightarrow \mathrm{MO}_{\mathrm{x}+1}+\mathrm{H}^{+}+\mathrm{e}^{-}
\end{aligned}
$$

This presupposes the existence of physisorbed (adsorbed ${ }^{\circ} \mathrm{OH}$ ) and chemisorbed $\left(\mathrm{MO}_{\mathrm{x}+1}\right)$ "active oxygen" at the anode surface. In the absence of pollutants, both states produce $\mathrm{O}_{2}$ according to the following reactions:

$$
\begin{gathered}
\mathrm{MO}_{\mathrm{x}}\left({ }^{\circ} \mathrm{OH}\right) \rightarrow 1 / 2 \mathrm{O}_{2}+\mathrm{MO}_{\mathrm{x}}+\mathrm{H}^{+}+\mathrm{e}^{-} \\
\mathrm{MO}_{\mathrm{x}+1} \rightarrow 1 / 2 \mathrm{O}_{2}+\mathrm{MO}_{\mathrm{x}}
\end{gathered}
$$

When an oxidizable organic $\mathrm{R}$ is present in the solution, the physisorbed "active oxygen" causes predominantly its complete mineralization by reaction (6) and the chemisorbed "active oxygen" participates in the formation of partially oxidized products $\mathrm{RO}$ by reaction (7).

$$
\begin{gathered}
\mathrm{R}+\mathrm{zMO}_{\mathrm{x}}\left({ }^{\bullet} \mathrm{OH}\right) \rightarrow \mathrm{CO}_{2}+\mathrm{H}_{2} \mathrm{O}+\mathrm{zMO}_{\mathrm{x}}+\mathrm{zH}^{+}+\mathrm{ze}^{-} \\
\mathrm{R}+\mathrm{MO}_{\mathrm{x}+1} \rightarrow \mathrm{RO}+\mathrm{MO}_{\mathrm{x}}
\end{gathered}
$$

Thus, electrochemical conversion is favored by anodes having a concentration of $\mathrm{MO}_{\mathrm{x}}\left(\mathrm{OH}^{\bullet}\right)$ near zero. This condition is achieved if the rate of transition of oxygen into the metallic oxide lattice by reaction (3) is much faster than that of hydroxyl radical formation by reaction (2). In contrast, electrochemical combustion takes place in anodes with high surface concentration of hydroxyl radicals because the rate of reaction (3) becomes insignificant. The current efficiency for both methods then depends on the relative rate of reactions (6) and (7) to that of its corresponding oxygen evolution reactions (4) and (5). For a BDD anode, reactions (2) and (6) are predominant leading to total mineralization of organics.

Electrochemical combustion involves hydroxylation (reaction (8)) or dehydrogenation (reaction (9)) of organics with hydroxyl radicals. In the last case, $\mathrm{O}_{2}$ can react with the resulting organic radical $\mathrm{R}^{\text {'• }}$ to give a very reactive hydroperoxyl radical $\mathrm{R}^{\prime} \mathrm{OO}^{\circ}$ (reaction (10)) able to abstract a hydrogen atom from another pollutant R"H (reaction (11)). The resulting organic hydroperoxides $\mathrm{R}^{\prime} \mathrm{OOH}$ are relatively unstable and decompose leading to molecular breakdown with generation of subsequent intermediates. These scission reactions continue until the final generation of $\mathrm{CO}_{2}$ and inorganic ions.

$$
\mathrm{R}+\mathrm{MO}_{\mathrm{x}}\left({ }^{\bullet} \mathrm{OH}\right) \rightarrow \mathrm{ROH}^{\bullet}+\mathrm{MO}_{\mathrm{x}}
$$




$$
\begin{gathered}
\mathrm{R}^{\prime} \mathrm{H}+\mathrm{MO}_{\mathrm{x}}\left({ }^{\bullet} \mathrm{OH}\right) \rightarrow \mathrm{R}^{\prime \bullet}+\mathrm{MO}_{\mathrm{x}}+\mathrm{H}_{2} \mathrm{O} \\
\mathrm{R}^{\prime \bullet}+\mathrm{O}_{2} \rightarrow \mathrm{R}^{\prime} \mathrm{OO}^{\bullet} \\
\mathrm{R}^{\prime} \mathrm{OO}^{\bullet}+\mathrm{R}^{\prime} \mathrm{H} \rightarrow \mathrm{R}^{\prime} \mathrm{OOH}+\mathrm{R}{ }^{\prime \bullet}
\end{gathered}
$$

\section{Indirect electrooxidation methods}

In the last years potent indirect electrooxidation methods involving continuous supply of hydrogen peroxide to the contaminated solution have been developed [41-68]. In acid medium, this oxidant is generated from the two-electron reduction of $\mathrm{O}_{2}$ gas:

$$
2 \mathrm{H}^{+}+2 \mathrm{e}^{-} \rightarrow \mathrm{H}_{2} \mathrm{O}_{2}
$$

Reaction (12) can take place on graphite [42], reticulated vitreous carbon $[41,43,47,50]$, mercury pool $[49,55]$, carbon-felt $[1,52,53,63,64,67]$ and $\mathrm{O}_{2^{-}}$ diffusion $[33,44-48,50,51,54,56-62,65,66,68]$ cathodes. The oxidation power of $\mathrm{H}_{2} \mathrm{O}_{2}$ is enhanced by addition of $\mathrm{Fe}^{2+}$ to the solution that allows the formation of -OH from the well-known Fenton's reaction between both species with a secondorder rate constant $k_{2}=53 \mathrm{M}^{-1} \mathrm{~s}^{-1}$ [69-71]:

$$
\mathrm{Fe}^{2+}+\mathrm{H}_{2} \mathrm{O}_{2} \rightarrow \mathrm{Fe}^{3+}+{ }^{\bullet} \mathrm{OH}+\mathrm{OH}^{-}
$$

- $\mathrm{OH}$ thus generated can rapidly react with $\mathrm{Fe}^{2+}$ to give $\mathrm{Fe}^{3+}$ :

$$
\mathrm{Fe}^{2+}+\cdot \mathrm{OH} \rightarrow \mathrm{Fe}^{3+}+\mathrm{OH}^{-}
$$

The $k_{2}$-value for reaction (14) is $4.3 \times 10^{8} \mathrm{M}^{-1} \mathrm{~s}^{-1}$ [71], several orders of magnitude higher than that of reaction (13). An advantage of the use of the $\mathrm{Fe}^{3+} / \mathrm{Fe}^{2+}$ catalytic system is that $\mathrm{Fe}^{2+}$ is not removed from the solution by the above reactions, since it is continuously regenerated in small extent from the reduction of $\mathrm{Fe}^{3+}$ at the cathode by reaction (15) or in the medium with electrogenerated $\mathrm{H}_{2} \mathrm{O}_{2}$ by reaction (16) with $k_{2}=3.1 \times 10^{-3} \mathrm{M}^{-1} \mathrm{~s}^{-1}$ [72], with hydroperoxyl radical $\left(\mathrm{HO}_{2}{ }^{\circ}\right)$ by reaction (17) with $k_{2}<1 \times 10^{3} \mathrm{M}^{-1} \mathrm{~s}^{-1}[73]$ and/or with organic radical intermediates $\mathrm{R}^{\bullet}$ by reaction (18). The existence of reactions (15)-(18) ensures the propagation of catalytic reaction (13) with the production of sufficient concentration of ${ }^{\circ} \mathrm{OH}$ in the medium for an efficient destruction of organic pollutants. Hydroperoxyl radical generated in them is a species with much weaker oxidation power than ${ }^{\circ} \mathrm{OH}$.

$$
\begin{gathered}
\mathrm{Fe}^{3+}+\mathrm{e}^{-} \rightarrow \mathrm{Fe}^{2+} \\
\mathrm{Fe}^{3+}+\mathrm{H}_{2} \mathrm{O}_{2} \rightarrow \mathrm{Fe}^{2+}+\mathrm{H}^{+}+\mathrm{HO}_{2} \\
\mathrm{Fe}^{3+}+\mathrm{HO}_{2} \rightarrow \mathrm{Fe}^{2+}+\mathrm{H}^{+}+\mathrm{O}_{2}
\end{gathered}
$$




$$
\mathrm{Fe}^{3+}+\mathrm{R}^{\cdot} \rightarrow \mathrm{Fe}^{2+}+\mathrm{R}^{+}
$$

The most typical indirect electrooxidation method with $\mathrm{H}_{2} \mathrm{O}_{2}$ electrogeneration is the so-called electro-Fenton process involving the production of electrogenerated Fenton's reagent (EFR) in an acid solution contained in the cathodic compartment of a divided cell $[1,41,42,49,50,52,53,55,63,64,67]$. After addition of a small concentration of $\mathrm{Fe}^{2+}$ or $\mathrm{Fe}^{3+}, \mathrm{O}_{2}$ is bubbled through the solution to yield $\mathrm{H}_{2} \mathrm{O}_{2}$ at the cathode from reaction (12) and then, organics are mineralized by the action of ${ }^{\circ} \mathrm{OH}$ generated from reaction (13). In our laboratory [33,44$46,51,54,56-62,65,66,68]$ we have applied the electro-Fenton process and other two AEOPs, the so-called photoelectro-Fenton and peroxi-coagulation processes, to the treatment of aromatic pollutants using an undivided cell with a carbonpolytetrafluoroethylene (PTFE) $\mathrm{O}_{2}$-fed cathode, able to produce quantitatively $\mathrm{H}_{2} \mathrm{O}_{2}$ in acid solutions from reaction (12). The electro-Fenton method is then carried out with a Pt or BDD anode and a small concentration of catalytic $\mathrm{Fe}^{2+}$ is added to the starting solution to permit the mineralization of contaminants by the combined action of ${ }^{\circ} \mathrm{OH}$ generated from reaction (1) at the anode and from reaction (13) in the medium. In photoelectro-Fenton, the solution is also irradiated with UVA light of $\lambda_{\max }=360 \mathrm{~nm}$ to try to accelerate the mineralization process by the photolysis of complexes of $\mathrm{Fe}^{3+}$ with some intermediates, e.g., oxalic acid [74], and/or by the enhancement of the rate of $\mathrm{Fe}^{2+}$ regeneration from additional photoreduction of $\mathrm{Fe}^{3+}$ species, such as $\mathrm{Fe}(\mathrm{OH})^{2+}$, via photo-Fenton reaction [69-71]:

$$
\mathrm{Fe}(\mathrm{OH})^{2+}+\mathrm{h} v \rightarrow \mathrm{Fe}^{2+}+{ }^{\bullet} \mathrm{OH}
$$

which takes place between 300 and $480 \mathrm{~nm}$. In both methods $\mathrm{H}_{2} \mathrm{O}_{2}$ electrogenerated at the cathode is oxidized to $\mathrm{O}_{2}$ at the anode via $\mathrm{HO}_{2}{ }^{\circ}$ :

$$
\begin{gathered}
\mathrm{H}_{2} \mathrm{O}_{2} \rightarrow \mathrm{HO}_{2}^{\cdot}+\mathrm{H}^{+}+\mathrm{e}^{-} \\
\mathrm{HO}_{2} \cdot \rightarrow \mathrm{O}_{2}+\mathrm{H}^{+}+\mathrm{e}^{-}
\end{gathered}
$$

In contrast, the peroxi-coagulation process uses a sacrificial $\mathrm{Fe}$ anode that continuously supplies soluble $\mathrm{Fe}^{2+}$ to the solution from the following anodic reaction [57-60]:

$$
\mathrm{Fe} \rightarrow \mathrm{Fe}^{2+}+2 \mathrm{e}^{-}
$$

$\mathrm{Fe}^{2+}$ thus produced is quickly oxidized by electrogenerated $\mathrm{H}_{2} \mathrm{O}_{2}$ from reaction (13) yielding a $\mathrm{Fe}^{3+}$ saturated solution, whereas the excess of this ion precipitates as hydrated $\mathrm{Fe}(\mathrm{III})$ oxide $\left(\mathrm{Fe}(\mathrm{OH})_{3}\right)$. Pollutants can then be removed by the combined action of their degradation with ${ }^{\circ} \mathrm{OH}$ generated from reaction (13) and their coagulation with the $\mathrm{Fe}(\mathrm{OH})_{3}$ precipitate formed. Peroxi-coagulation differs from classical electrocoagulation with an $\mathrm{Fe}$ anode and an inert cathode, where no soluble organics are degraded because no $\mathrm{H}_{2} \mathrm{O}_{2}$ is produced in the medium. A similar procedure is the so-called anodic Fenton treatment (AFT) $[75,76]$ in 
which $\mathrm{H}_{2} \mathrm{O}_{2}$ is directly added to the treated solution contained in the anodic compartment of a divided cell with an Fe anode.

\section{Electrolytic cell and experimental conditions}

Comparative treatments of acidic aqueous solutions of aromatics by AEOPs were carried out in our laboratory using an undivided electrolytic cell under galvanostatic conditions. Fig. 1 shows a scheme of the cylindrical glass cell with a jacket to maintain the solution temperature under water circulation through an external thermostat [44]. The cell contained $100 \mathrm{~mL}$ of a contaminated solution vigorously stirred with a magnetic bar. The cathode was a $3.1-\mathrm{cm}^{2}$ carbon-PTFE electrode from E-TEK, placed at the extreme of a holder of polypropylene and mounted onto a nickel screen of 125 meshes that served as current distributor in contact with a nichrome wire as electrical connection. It was fed with pure $\mathrm{O}_{2}$ at a flow rate of $20 \mathrm{~mL} \mathrm{~min} \mathrm{~m}^{-1}$, injected from an oxygen cylinder through a tube inside the holder up to inner face of the electrode. The PTFE permitted the diffusion of the gas to the solution where it was reduced to $\mathrm{H}_{2} \mathrm{O}_{2}$ on the carbon surface following reaction (12), while the $\mathrm{O}_{2}$ in excess was released to the atmosphere through the open top of the holder. For direct anodic oxidation, a 3$\mathrm{cm}^{2}$ graphite bar from Sofacel was used as alternative cathode, without $\mathrm{H}_{2} \mathrm{O}_{2}$ accumulation in the solution [51]. The anode was a $10-\mathrm{cm}^{2} \mathrm{Pt}$ sheet of $99.99 \%$

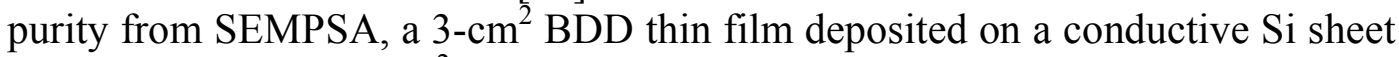
from CSEM or a $10-\mathrm{cm}^{2} \mathrm{Fe}$ sheet of $99.99 \%$ purity from Goodfellow. In this way, AEOPs with $\mathrm{Pt} / \mathrm{O}_{2}, \mathrm{BDD} / \mathrm{O}_{2}$ and $\mathrm{Fe} / \mathrm{O}_{2}$ cells were tested. The interelectrode gap was maintained at about $1 \mathrm{~cm}$.

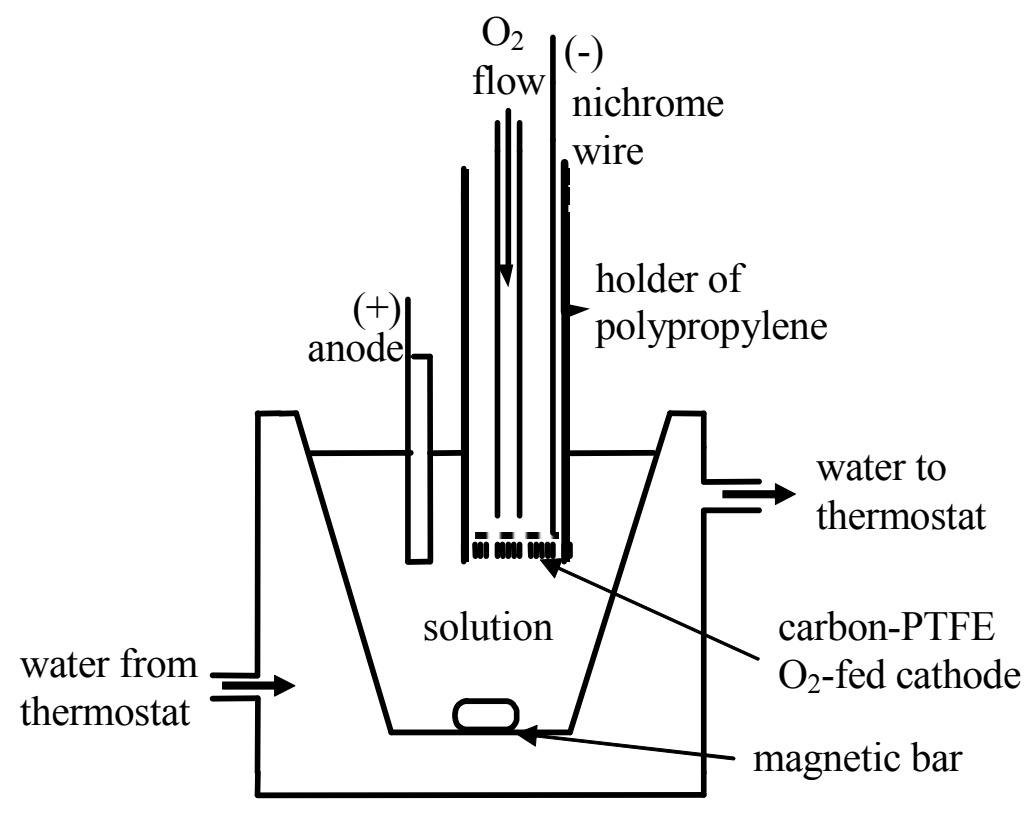

Figure 1. Cylindrical two-electrode cell of $100 \mathrm{~mL}$ capacity with an $\mathrm{O}_{2}$-diffusion cathode used for the destruction of organic contaminants in waters by means of AEOPs [44]. 
Initial aromatic contaminants and their detected by-products were reagent grade from Avocado, Fluka, Merck, Panreac and Probus. They were used without further purification, except aniline that was previously bidistilled at $178-180{ }^{\circ} \mathrm{C}$ under atmospheric pressure. All acidic solutions were prepared with high-purity water obtained from a Millipore Milli-Q system, with resistivity $>18 \mathrm{M} \Omega \mathrm{cm}$ at $25{ }^{\circ} \mathrm{C}$. The initial solution $\mathrm{pH}$ was adjusted with analytical grade sulfuric acid supplied by Merck. Anhydrous sodium sulfate, used as background electrolyte, and heptahydrated ferrous sulfate, used as catalyst, were analytical grade from Fluka. Organic solvents and the other chemicals employed were either HPLC or analytical grade from Merck, Fluka and Aldrich.

The different aromatic pollutants were comparatively degraded in the same acidic aqueous media with $0.05 \mathrm{M} \mathrm{Na}_{2} \mathrm{SO}_{4}$ as background electrolyte and $\mathrm{H}_{2} \mathrm{SO}_{4}$ to regulate its initial $\mathrm{pH}$ in the range 2.0-6.0. Solutions with an initial organic concentration equivalent to about $100 \mathrm{mg} \mathrm{L}^{-1}$ of TOC were electrolyzed at a constant current of 100, 300 and $450 \mathrm{~mA}$. The temperature was maintained at 25 ${ }^{\circ} \mathrm{C}$ or $35^{\circ} \mathrm{C}$. Electro-Fenton and photoelectro-Fenton methods were usually performed by adding $1 \mathrm{mM} \mathrm{FeSO}$ to all solutions. In photoelectro-Fenton the solution was irradiated with UVA light supplied by a Philips $6 \mathrm{~W}$ fluorescent black light blue tube placed at $7 \mathrm{~cm}$ above its surface, which emitted in the wavelength region between 300 and $400 \mathrm{~nm}$ with $\lambda_{\max }=360 \mathrm{~nm}$. It supplied a photoionization energy input to the solution of $140 \mu \mathrm{W} \mathrm{cm}{ }^{-2}$, detected with a NRC 820 laser power meter working at $514 \mathrm{~nm}$. During the peroxi-coagulation treatments, the solution $\mathrm{pH}$ was continuously regulated by adding small volumes of $0.5 \mathrm{M} \mathrm{H}_{2} \mathrm{SO}_{4}$ every 10 or 20 min until a volume of $5 \mathrm{~mL}$ as maximum.

Electrochemical treatments were carried out with an Amel 551, 552 or 2049 potentiostat-galvanostat. The solution $\mathrm{pH}$ was measured with a Crison $2000 \mathrm{pH}$ meter. All samples extracted from electrolyzed solutions were filtered with 0.45 $\mu \mathrm{m}$ PTFE filters from Whatman before analysis. $\mathrm{H}_{2} \mathrm{O}_{2}$ concentration accumulated during electrolysis was determined by measuring the light absorption of the titanic-hydrogen peroxide colored complex at $\lambda=420 \mathrm{~nm}$ [51]. The degradation of aromatic solutions was monitored by their total organic carbon (TOC) removal, determined on a Shimadzu 5050 TOC analyzer using the standard non purgeable organic carbon method. The decay of initial pollutants and the evolution of their aromatic products were followed by reversed-phase chromatography with a Waters 600 HPLC liquid chromatograph fitted with a Spherisorb ODS2 $5 \mu \mathrm{m}, 150 \times 4.6 \mathrm{~mm}$, column at room temperature, coupled with a Waters 996 photodiode array detector selected at $280 \mathrm{~nm}$ and controlled through a Millennium-32 ${ }^{\circledR}$ program. These analyses were made by injecting 20 $\mu \mathrm{L}$ aliquots into the HPLC chromatograph and circulating a mixture of $60: 40$ $(\mathrm{v} / \mathrm{v})$ acetonitrile/phosphate buffer $(\mathrm{pH} 3.1)$ or 50:45:5 (v/v/v) methanol/phosphate buffer $(\mathrm{pH} 2.5) /$ pentanol as mobile phase at $1.0 \mathrm{~mL} \mathrm{~min} \mathrm{~m}^{-1}$. Generated carboxylic acids were analyzed by ion-exclusion chromatography, using the above HPLC chromatograph fitted with a Bio-Rad Aminex HPX $87 \mathrm{H}$, $300 \times 7.8 \mathrm{~mm}$, column at $35^{\circ} \mathrm{C}$ and selecting the photodiode array detector at $210 \mathrm{~nm}$. In this technique, $20-\mu \mathrm{L}$ aliquots were also injected into the chromatograph and the mobile phase was $4 \mathrm{mM} \mathrm{H}_{2} \mathrm{SO}_{4}$ at $0.6 \mathrm{~mL} \mathrm{~min}{ }^{-1}$. The $\mathrm{Cl}^{-}$ 
concentration in solution at a given electrolysis time was determined by standard potentiometric titration with $\mathrm{AgNO}_{3}$.

\section{AEOPs with a $\mathrm{Pt} / \mathrm{O}_{2}$ cell}

The ability of the $\mathrm{Pt} / \mathrm{O}_{2}$ cell to accumulate the $\mathrm{H}_{2} \mathrm{O}_{2}$ supplied by the carbon-PTFE $\mathrm{O}_{2}$-fed cathode from reaction (12) was characterized by electrolyzing $100 \mathrm{~mL}$ of $0.05 \mathrm{M} \mathrm{Na}_{2} \mathrm{SO}_{4}+\mathrm{H}_{2} \mathrm{SO}_{4}$ solutions of $\mathrm{pH} 3.0$ under different conditions. Fig. 2 shows a gradual increase in $\mathrm{H}_{2} \mathrm{O}_{2}$ concentration in solution at $450 \mathrm{~mA}$ (curve $a$ ), $300 \mathrm{~mA}$ (curve $b$ ) and $100 \mathrm{~mA}$ (curve $e$ ) during the initial $2 \mathrm{~h}$ of electrolysis. After $3 \mathrm{~h}$, the accumulated $\mathrm{H}_{2} \mathrm{O}_{2}$ reaches a steady concentration of 73,47 and 17 $\mathrm{mM}$, respectively, values directly proportional to the applied current. This behavior can be explained assuming that, in the steady state, $\mathrm{H}_{2} \mathrm{O}_{2}$ is electrogenerated and simultaneously destroyed in the system at the same rate. The fact that its steady concentration is proportional to the current suggests that it mainly undergoes chemical and electrochemical decomposition to $\mathrm{O}_{2}$ at the $\mathrm{Pt}$ anode. The last process takes place via $\mathrm{HO}_{2}{ }^{\bullet}$ formation following reactions (20) and (21), which compete with anodic oxidation of water to $\mathrm{O}_{2}$ initiated by reaction (1). When $1 \mathrm{mM} \mathrm{Fe}^{2+}$ is added to the solution electrolyzed at $300 \mathrm{~mA}$ (electro-Fenton conditions), less $\mathrm{H}_{2} \mathrm{O}_{2}$ is accumulated, as can be deduced by comparing curves $b$ and $c$ of Fig. 2. This slightly lower steady concentration can be related to more decomposition of $\mathrm{H}_{2} \mathrm{O}_{2}$ by the action of $\mathrm{Fe}^{2+}$ from Fenton's reaction (13) and $\mathrm{Fe}^{3+}$ from reaction (16). Operating under photoelectro-Fenton conditions at $300 \mathrm{~mA}$, a higher decay in accumulated $\mathrm{H}_{2} \mathrm{O}_{2}$ can be even observed in curve $d$ of Figure 2, since UVA irradiation enhances $\mathrm{Fe}^{2+}$ regeneration from reaction (19), leading to an increase in rate of reactions (13) and (16). In all cases a gradual decay in solution $\mathrm{pH}$ with electrolysis time was observed. Final $\mathrm{pH}$ values of 2.8, 2.6 and 2.0 were found after $6 \mathrm{~h}$ of electrolysis at 100, 300 and 450 $\mathrm{mA}$, respectively, regardless of the method tested. The current efficiency for $\mathrm{H}_{2} \mathrm{O}_{2}$ accumulation, considering that only reaction (12) occurs at the cathode, was always independent of the applied current, although it decreased with time. According to results of Figure 2, the highest current efficiency was obtained in the experiments without $\mathrm{Fe}^{2+}$, where its value fell from ca. $80 \%$ at $15 \mathrm{~min}$ to ca. $50 \%$ at $2 \mathrm{~h}$.

The above results confirm that the rate of $\mathrm{H}_{2} \mathrm{O}_{2}$ production in the $\mathrm{Pt} / \mathrm{O}_{2}$ cell is high enough to destroy relatively concentrated solutions of organic contaminants. The degradation of aromatics such as aniline [44,45], 4-chlorophenol [46], 4CPA (4-chlorophenoxyacetic acid) [56] and 2,4-D (2,4-dichlorophenoxyacetic acid) [51] were then studied to compare the oxidation power of electro-Fenton and photoelectro-Fenton with that of anodic oxidation.

The progressive TOC decay found for $100 \mathrm{~mL}$ of solutions of $\mathrm{pH} 3.0$ with 100 $\mathrm{mg} \mathrm{L}{ }^{-1}$ of aniline at $25^{\circ} \mathrm{C}, 178 \mathrm{mg} \mathrm{L}^{-1}$ of 4-chlorophenol at $25^{\circ} \mathrm{C}, 194 \mathrm{mg} \mathrm{L}^{-1}$ of 4-CPA at $35^{\circ} \mathrm{C}$ and $230 \mathrm{mg} \mathrm{L}^{-1}$ of $2,4-\mathrm{D}$ at $25^{\circ} \mathrm{C}$ by the above treatments at 100 $\mathrm{mA}$ is depicted in Fig. 3(a), 3(b), 3(c) and 3(d), respectively. After $6 \mathrm{~h}$ of electrolysis, the final $\mathrm{pH}$ of all solutions was 2.6-2.8, indicating that this parameter remains practically constant in all cases. Fig. 3(a)-3(d) show that direct anodic oxidation and anodic oxidation in the presence of electrogenerated $\mathrm{H}_{2} \mathrm{O}_{2}$ 
yield a very slow degradation of all contaminants for $6 \mathrm{~h}$, reaching about $25-30 \%$ of mineralization.

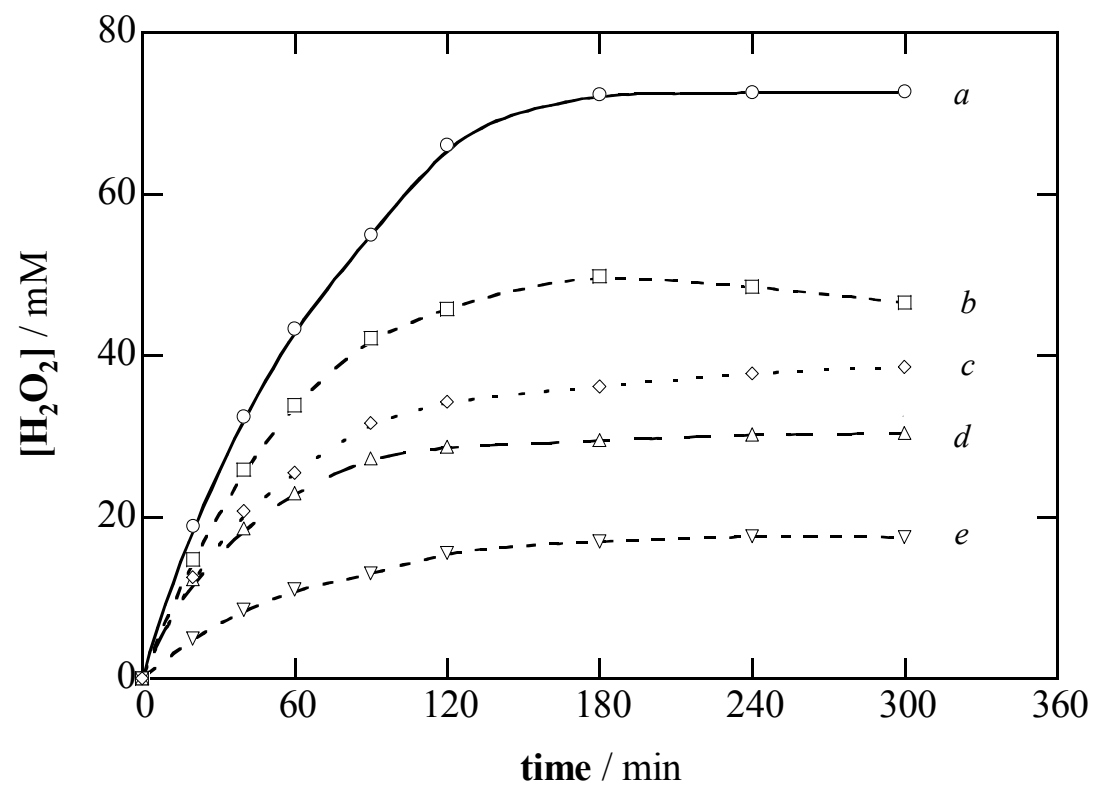

Figure 2. Dependence of accumulated $\mathrm{H}_{2} \mathrm{O}_{2}$ concentration on time for $100 \mathrm{~mL}$ of a 0.05 $\mathrm{M} \mathrm{Na}_{2} \mathrm{SO}_{4}+\mathrm{H}_{2} \mathrm{SO}_{4}$ solution of $\mathrm{pH} 3.0$ electrolyzed in a $\mathrm{Pt} / \mathrm{O}_{2}$ cell [51]. (a), (b), (e) without $\mathrm{Fe}^{2+},(c)$ in the presence of $1 \mathrm{mM} \mathrm{Fe}^{2+}$ (electro-Fenton conditions), (d) in the presence of $1 \mathrm{mM} \mathrm{Fe}^{2+}$ and under irradiation of a $6 \mathrm{~W} \mathrm{UVA} \mathrm{light} \mathrm{of} \lambda_{\max }=360 \mathrm{~nm}$ (photoelectro-Fenton conditions). Applied current: (a) 450, (b), (c), (d) 300, (e) 100 $\mathrm{mA}$. Temperature $25^{\circ} \mathrm{C}$.

The low oxidation ability of both methods can be ascribed to the small concentration of reactive ${ }^{\circ} \mathrm{OH}$ formed on the $\mathrm{Pt}$ anode surface from reaction (1), which is the main oxidant agent of organics since the presence of $\mathrm{H}_{2} \mathrm{O}_{2}$ only causes a slightly faster TOC abatement (see Fig. 3(c) and 3(d)). In contrast, the electro-Fenton treatment with $1 \mathrm{mM} \mathrm{Fe}^{2+}$ has much higher oxidation power, leading to $60-90 \%$ of decontamination. A more rapid TOC removal can be observed for photoelectro-Fenton, which gives complete mineralization $(>95 \%$ of TOC decay) from $4 \mathrm{~h}$. The fast degradation found during the first stages of electro-Fenton can be related to the existence of quick homogeneous reactions of organics with great amounts of ${ }^{\circ} \mathrm{OH}$ produced from reaction (13), remaining in the solution products that are not attacked by this radical. The photodecomposition of such products and/or the enhancement of the generation rate of ${ }^{\circ} \mathrm{OH}$ by the action of reaction (19) could then account for the highest mineralization rate of photoelectro-Fenton, which is the AEOP with the greatest oxidation power in the $\mathrm{Pt} / \mathrm{O}_{2}$ system.

The effect of different experimental parameters on the degradation of the above aromatics was also investigated. It was found that increasing current causes quicker mineralization rate in all AEOPs due to the concomitant production of more ${ }^{\circ} \mathrm{OH}$ at the anode surface from reaction (1) and/or in the medium from 
reaction (13) because more $\mathrm{H}_{2} \mathrm{O}_{2}$ is accumulated (see Fig. 2). Similar TOC-time plots were also obtained in electro-Fenton and photoelectro-Fenton with $\mathrm{Fe}^{2+}$ concentrations between 0.2 and $1 \mathrm{mM}$, suggesting that low amount of this catalyst is needed for an efficient production of ${ }^{\circ} \mathrm{OH}$. However, a more significant influence was observed for both methods by varying the solution $\mathrm{pH}$. As an example, Fig. 4 shows the TOC decay for $194 \mathrm{mg} \mathrm{L}^{-1} 4-\mathrm{CPA}$ and $1 \mathrm{mM}$ $\mathrm{Fe}^{2+}$ solutions in the $\mathrm{pH}$ range 2.0-6.0 under photoelectro-Fenton treatment. The maximum rate for 4-CPA degradation is achieved at $\mathrm{pH} 3.0$, although the herbicide is completely destroyed in all acid media. This behavior agrees with the fact that the optimum rate for Fenton's reaction (13) is 2.8 [69]. In general, all aromatic pollutants are more effectively degraded at $\mathrm{pH} 3.0-4.0$ by electroFenton and photoelectro-Fenton. This effect is not significant for the anodic oxidation processes.
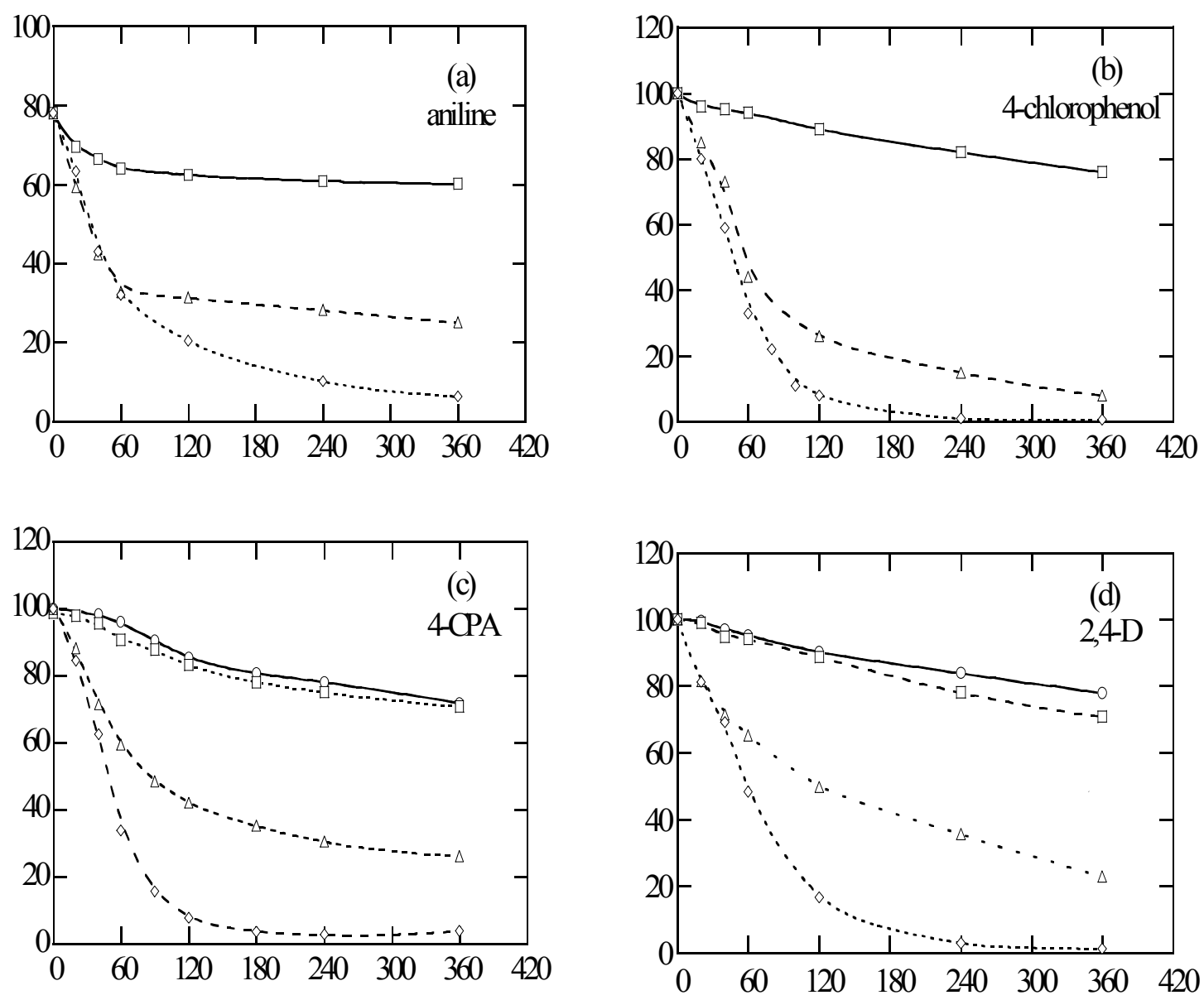

Figure 3. TOC removal with electrolysis time for $100 \mathrm{~mL}$ of: (a) $100 \mathrm{mg} \mathrm{L}^{-1}$ aniline

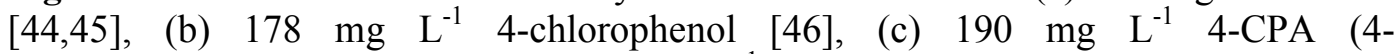
chlorophenoxyacetic acid) [56], (d) $230 \mathrm{mg} \mathrm{L}^{-1}$ 2,4-D (2,4-dichlorophenoxyacetic acid) [51] solutions in $0.05 \mathrm{M} \mathrm{Na}_{2} \mathrm{SO}_{4}+\mathrm{H}_{2} \mathrm{SO}_{4}$ of $\mathrm{pH} 3.0$ using a $\mathrm{Pt} / \mathrm{O}_{2}$ cell at $100 \mathrm{~mA}$. Temperature: (a), (b), (d) $25^{\circ} \mathrm{C}$, (c) $35^{\circ} \mathrm{C}$. Method: (O) anodic oxidation, ( $\square$ ) anodic oxidation in the presence of electrogenerated $\mathrm{H}_{2} \mathrm{O}_{2},(\Delta)$ electro-Fenton with $1 \mathrm{mM} \mathrm{Fe}^{2+}$, $(\diamond)$ photoelectro-Fenton with $1 \mathrm{mM} \mathrm{Fe}^{2+}$ and UVA light. 


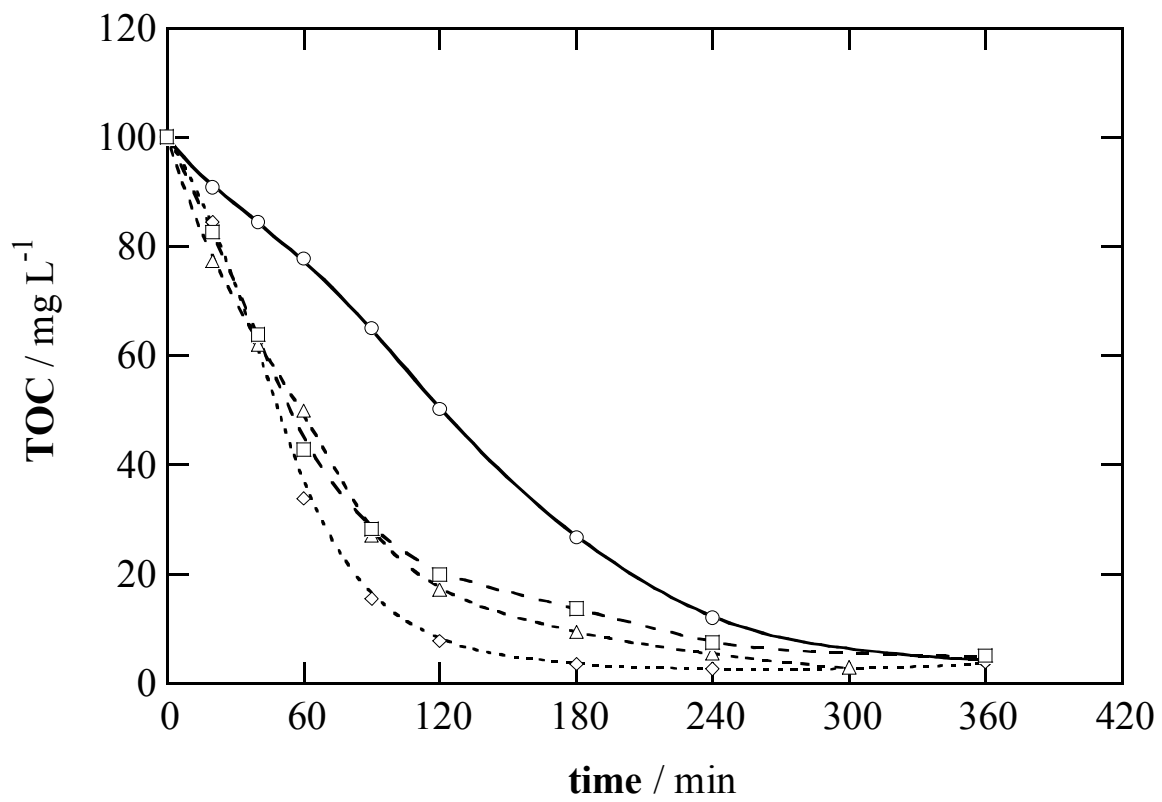

Figure 4. Influence of $\mathrm{pH}$ upon TOC abatement of 100-mL solutions containing 194 $\mathrm{mg} \mathrm{L}^{-1}$ 4-CPA and $1 \mathrm{~mm} \mathrm{Fe}^{2+}$ under photoelectro-fenton treatment at $100 \mathrm{~mA}$ and at 35 ${ }^{\circ} \mathrm{C}$ [56]. Initial solution $\mathrm{pH}:(\bigcirc)$ 2.0, $(\diamond) 3.0,(\square) 4.0,(\Delta) 6.0$.

The kinetics for aromatic decays at $100 \mathrm{~mA}$ was further followed by reversedphase chromatography. Aniline (see Fig. 5(a)) and 4-chlorophenol (see Fig. 5(b)) disappear from the medium after $3 \mathrm{~h}$ of direct anodic oxidation, while 4-CPA (see Fig. 5(c)) and 2,4-D (see Fig. 5(d)) are removed at $6 \mathrm{~h}$ and $5 \mathrm{~h}$, respectively. The two latter compounds are more rapidly destroyed by anodic oxidation in the presence of electrogenerated $\mathrm{H}_{2} \mathrm{O}_{2}$, indicating that this species slowly oxidizes the aromatic contaminants. As can be seen in Fig. 5(a)-5(d), electro-Fenton and photoelectro-Fenton methods yield a much faster decay of all initial aromatics, which are completely removed in less than $40 \mathrm{~min}$. The fact that their destruction rate is quite similar in both processes suggests that they mainly react with ${ }^{\circ} \mathrm{OH}$ generated from Fenton's reaction (13), without photodecomposition by the action of UVA light and without significant participation of photo-Fenton reaction (19). The evolution of by-products formed during the degradation of the above aromatic pollutants by AEOPs was also followed by HPLC. Fig. 6 presents the time-course of selected compounds detected during the treatment of $210 \mathrm{mg} \mathrm{L}^{-1}$ 4-CPA solutions of pH 3.0 at $100 \mathrm{~mA}$ [56]. As can be seen, 4-chlorophenol (Fig. 6(a)) and glycolic acid (Fig. 6(b)), which are the primary products of 4-CPA, are slowly destroyed by the two anodic oxidation methods, but very quickly degraded by electro-Fenton and photoelectro-Fenton. The evolution of 4chlorophenol is very similar in the two last processes, as expected if aromatics are not photodecomposed by UVA light, as stated above. In contrast, glycolic acid disappears more rapidly in photoelectro-Fenton, probably due to the fast 
photodegradation of its complexes with $\mathrm{Fe}^{3+}$. The same trends were found for the other intermediates, except oxalic acid. Fig. 6(c) shows that this acid is accumulated in electro-Fenton and rapidly photodecarboxylated in photoelectroFenton.
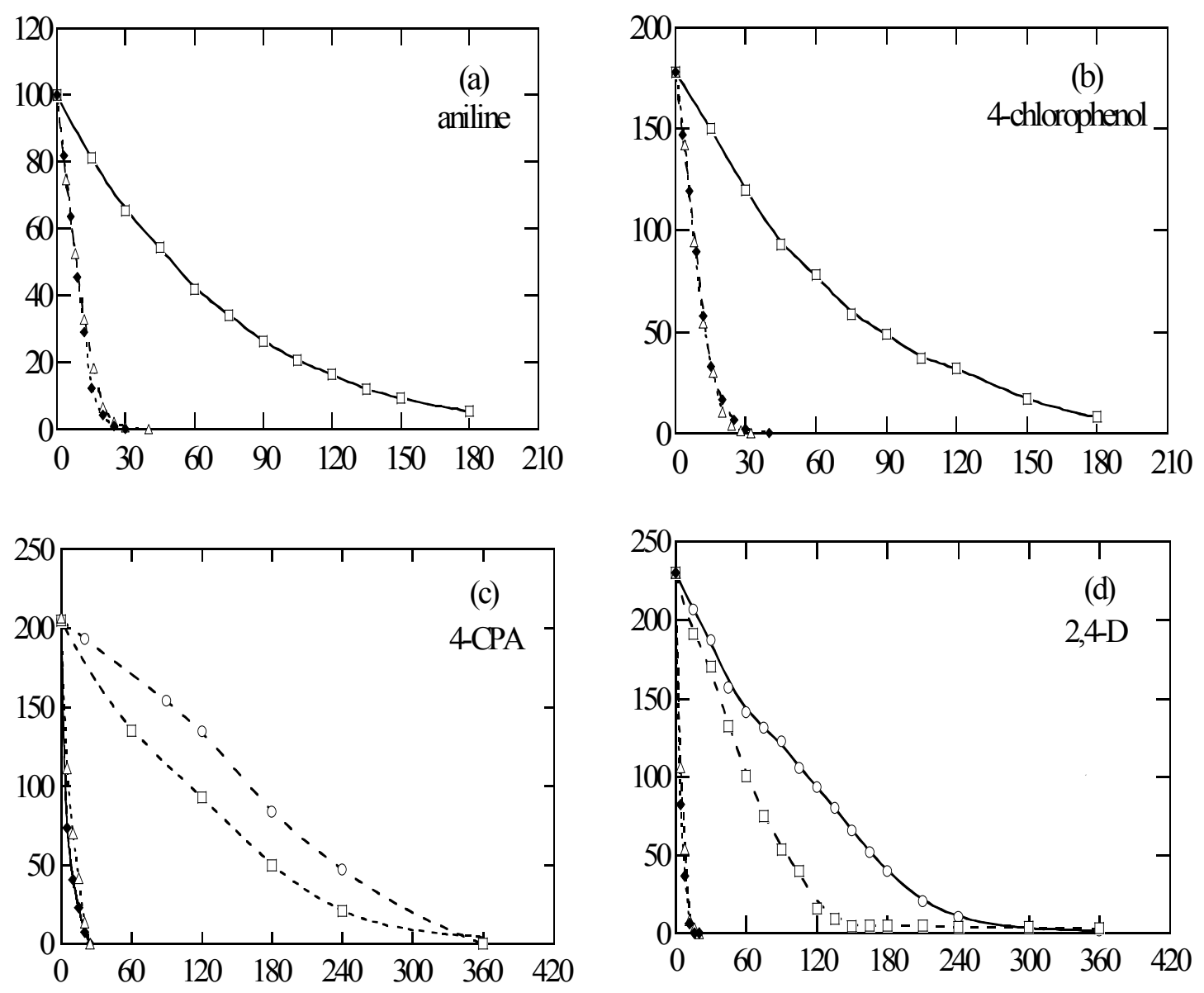

Figure 5. Decay of the concentration of: (a) aniline, (b) 4-chlorophenol, (c) 4-CPA, (d) 2,4-D for the experiments shown in Fig. 3. Applied methods: $(O)$ anodic oxidation, $(\square)$ anodic oxidation in the presence of electrogenerated $\mathrm{H}_{2} \mathrm{O}_{2},(\Delta)$ electro-Fenton with 1 $\mathrm{mM} \mathrm{Fe}^{2+},(\diamond)$ photoelectro-Fenton with $1 \mathrm{mM} \mathrm{Fe}^{2+}$ and UVA light. 

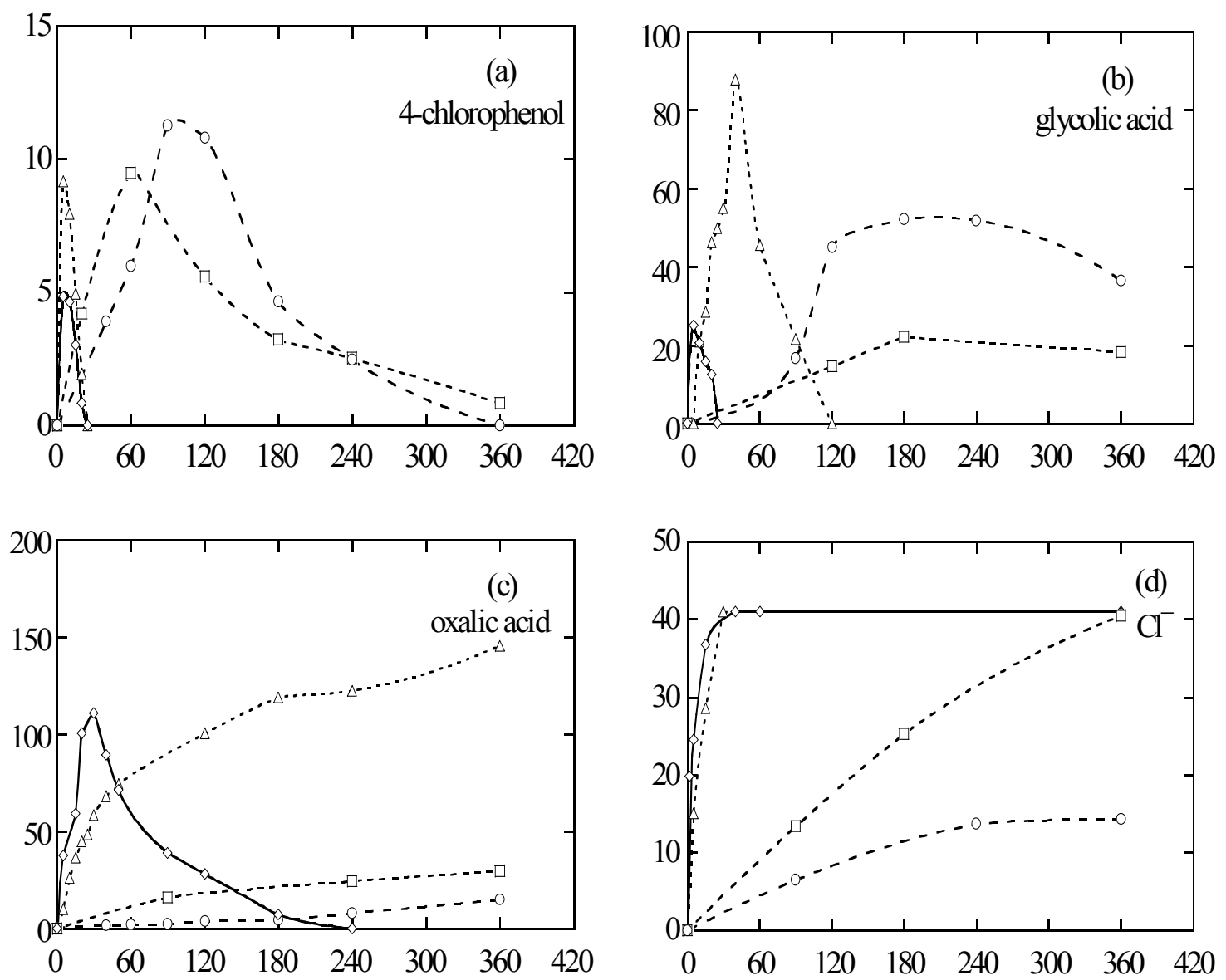

Figure 6. Evolution of the concentration of selected products detected during the degradation of $210 \mathrm{ppm}$ 4-CPA solutions under the conditions shown in Fig. 3 by (O) anodic oxidation, $(\square)$ anodic oxidation in the presence of electrogenerated $\mathrm{H}_{2} \mathrm{O}_{2},(\Delta)$ electro-Fenton, $(\diamond)$ photoelectro-Fenton [56]. Plots correspond to: (a) 4-chlorophenol, (b) glycolic acid, (c) oxalic acid, (d) chloride ion.

These results agree with the work of Zuo and Hoigné [74] who showed that oxalic acid and $\mathrm{Fe}^{3+}$ form stable complexes, which are photodecarboxylated by UVA light. Then, a high proportion of $\mathrm{Fe}^{3+}$-oxalato complexes is expected in the solutions of $\mathrm{pH} 3.0$ treated by AEOPs where $\mathrm{Fe}^{3+}$ is produced from Fenton's reaction (13). The low oxidation capability of ${ }^{\bullet} \mathrm{OH}$ to destroy such complexes could justify the slow TOC abatement at the end of electro-Fenton (see Fig. 3(c)), while the fast photodecomposition of $\mathrm{Fe}^{3+}$-oxalato complexes by UVA light could account for the total mineralization achieved in photoelectro-Fenton, also explaining the highest oxidation power of this procedure. Mineralization of 4CPA causes the loss of its initial chlorine in the form of chloride ion. As can be seen in Fig. 6(d), all $\mathrm{Cl}^{-}$is released after 30-40 min of electro-Fenton and photoelectro-Fenton, that is, when chlorine intermediates are totally destroyed (see Fig. 6(a)). 


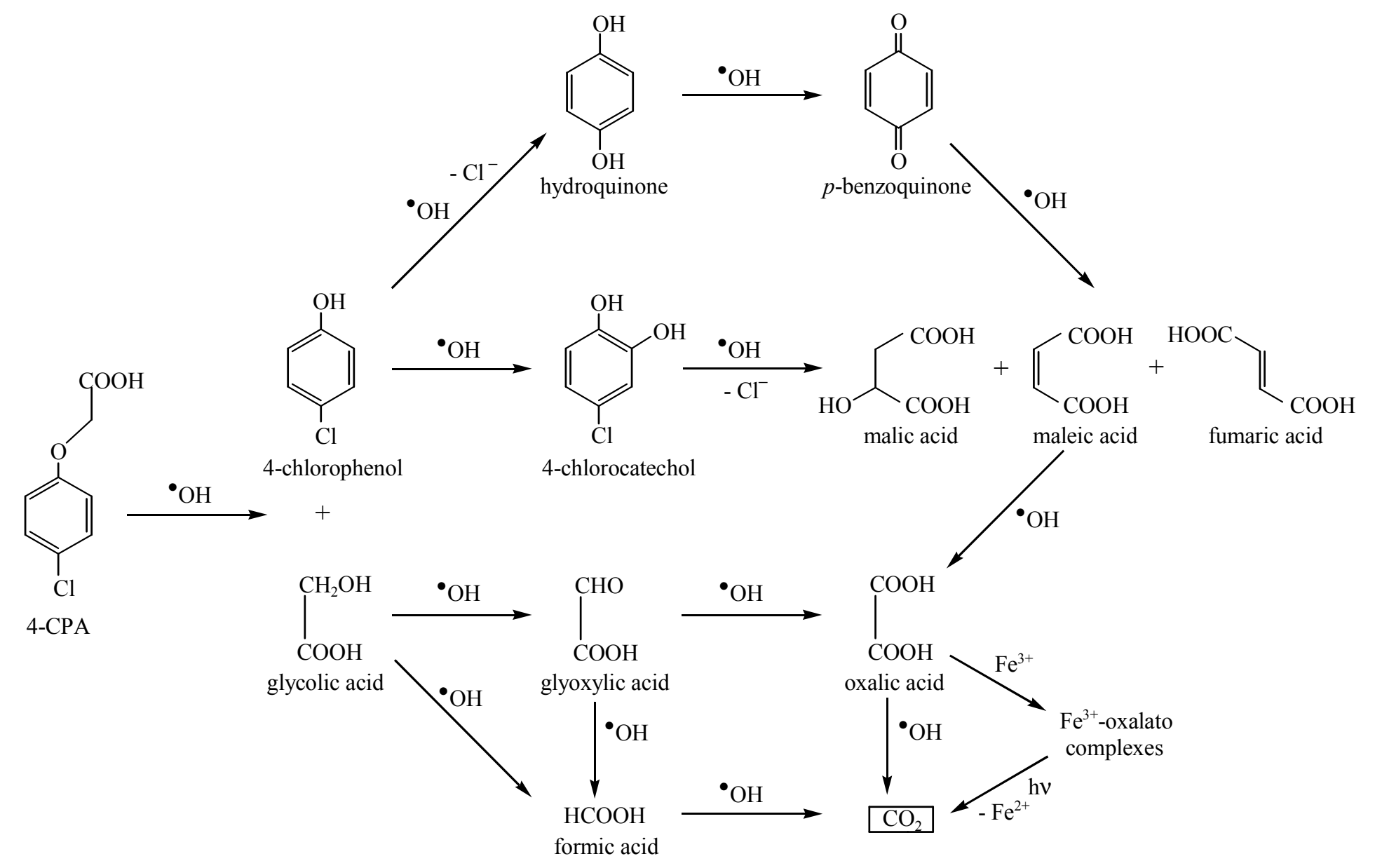

Figure 7. Proposed reaction sequence for the degradation of 4-CPA by AEOPs with a $\mathrm{Pt} / \mathrm{O}_{2}$ cell [56]. 
The accumulation of $\mathrm{Cl}^{-}$in the medium in the two anodic oxidation processes is much slower because chorine intermediates are slowly degraded.

A reaction sequence for the degradation of 4-CPA by AEOPs with a $\mathrm{Pt} / \mathrm{O}_{2}$ cell is proposed in Fig. 7. This pathway involves all intermediates detected by HPLC and assumes that ${ }^{\circ} \mathrm{OH}$ is the main oxidant for simplicity. The initial breaking of the lateral chain of 4-CPA via $\mathrm{C}(1)-\mathrm{O}$ bond produces 4-chlorophenol and glycolic acid. Hydroxylation on C(2)-position of 4-chlorophenol leads to 4chlorocatechol, while parallel ${ }^{\circ} \mathrm{OH}$ attack on its $\mathrm{C}(4)$-position gives hydroquinone with loss of $\mathrm{Cl}^{-}$. Hydroquinone is subsequently dehydrogenated to $p$-benzoquinone. Further oxidation of 4-chlorocatechol, with release of $\mathrm{Cl}^{-}$, and $p$-benzoquinone leads to malic, maleic, and fumaric acids, which are degraded to oxalic acid. This acid can also be formed from dehydrogenation of the initially generated glycolic acid, followed by hydroxylation of the resulting glyoxylic acid. Parallel oxidation of both glycolic and glyoxylic acids produces formic acid, which is converted into $\mathrm{CO}_{2}$. Oxalic acid is slowly transformed into $\mathrm{CO}_{2}$ by the two anodic oxidation methods, while in the AEOPs with iron ions, it gives complexes with $\mathrm{Fe}^{3+}$.

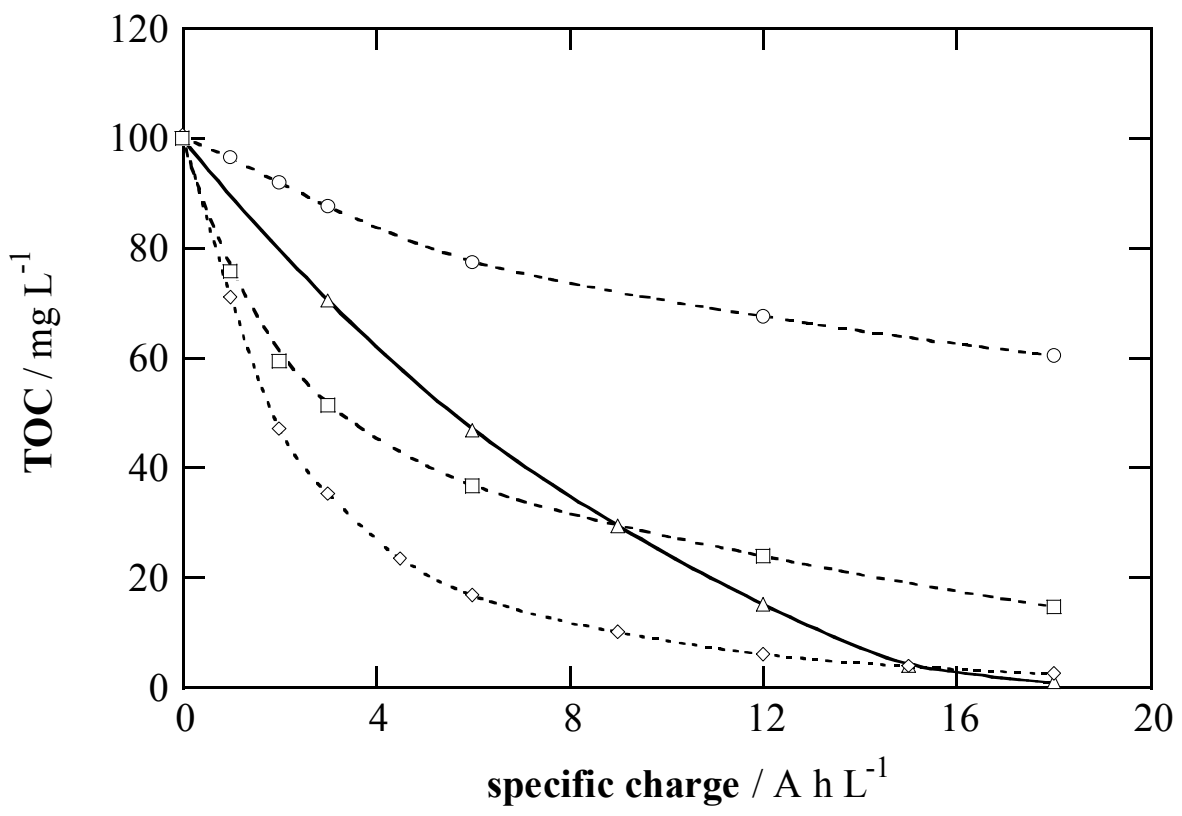

Figure 8. Comparative TOC abatement with specific charge for the degradation of 100 $\mathrm{mL}$ of $230 \mathrm{mg} \mathrm{L}^{-1} 2,4-\mathrm{D}$ solutions in $0.05 \mathrm{M} \mathrm{Na}_{2} \mathrm{SO}_{4}+\mathrm{H}_{2} \mathrm{SO}_{4}$ of $\mathrm{pH} 3.0$ at $300 \mathrm{~mA}$ and at $35^{\circ} \mathrm{C}$ [33]. Method: (O) anodic oxidation with a $10-\mathrm{cm}^{2} \mathrm{Pt}$ anode and a $3.1-\mathrm{cm}^{2} \mathrm{O}_{2-}$ diffusion cathode, $(\square)$ electro-Fenton with a $10-\mathrm{cm}^{2} \mathrm{Pt}$ anode, a $3.1-\mathrm{cm}^{2} \mathrm{O}_{2}$-diffusion cathode and $1 \mathrm{mM} \mathrm{Fe}{ }^{2+},(\Delta)$ anodic oxidation with a $3-\mathrm{cm}^{2}$ BDD anode and a $3-\mathrm{cm}^{2}$ graphite cathode, $(\diamond)$ electro-Fenton with a $3-\mathrm{cm}^{2} \mathrm{BDD}$ anode, a 3.1- $\mathrm{cm}^{2} \mathrm{O}_{2}$-diffusion cathode and $1 \mathrm{mM} \mathrm{Fe}^{2+}$. 
These complexes are slowly mineralized in electro-Fenton and quickly photodecarboxylated with loss of $\mathrm{Fe}^{2+}$, as proposed by Zuo and Hoigné [74] in photoelectro-Fenton. A similar photodecarboxylation of complexes of $\mathrm{Fe}^{3+}$ with the other generated acids can also take place.

\section{AEOPs with a BDD/O 2 cell}

Chlorophenoxyacetic acid herbicides such as 4-CPA, 2,4-D, MCPA (4-chloro-2methylphenoxyacetic acid) and 2,4,5-T (2,4,5-trichlorophenoxyacetic acid) were comparatively degraded by anodic oxidation and electro-Fenton with $\mathrm{Pt} / \mathrm{O}_{2}$ and $\mathrm{BDD} / \mathrm{O}_{2}$ cells to know the oxidation power of these electrolytic systems [33]. Fig. 8 shows the TOC decay versus consumed specific charge (in $\mathrm{A} \mathrm{h} \mathrm{L}^{-1}$ ) for a $230 \mathrm{mg} \mathrm{L}^{-1} 2,4-\mathrm{D}$ solution treated at $300 \mathrm{~mA}$ for $6 \mathrm{~h}$ by such methods. A quite slow degradation of 2,4-D and its derivatives can be observed for anodic oxidation with $\mathrm{Pt}$ in the presence of electrogenerated $\mathrm{H}_{2} \mathrm{O}_{2}$ up to attain about $40 \%$ of TOC removal at $6 \mathrm{~h}$, when $18 \mathrm{~A} \mathrm{~h} \mathrm{~L}^{-1}$ are consumed. This evidences the generation of a very small concentration of the main oxidant ${ }^{\circ} \mathrm{OH}$ on the $\mathrm{Pt}$ surface from reaction (1), as well as a poor parallel decontamination with $\mathrm{H}_{2} \mathrm{O}_{2}$. Electro-Fenton with $\mathrm{Pt}$ and $1 \mathrm{mM} \mathrm{Fe} \mathrm{F}^{2+}$ causes quicker mineralization by fast homogeneous reactions of pollutants with ${ }^{\circ} \mathrm{OH}$ produced from reaction (13). In this case the degradation rate decreases as specific charge rises from $6 \mathrm{~A} \mathrm{~h} \mathrm{~L}^{-1}$, because of the formation of products that are not oxidized by ${ }^{\bullet} \mathrm{OH}$, leading to $85 \%$ of final TOC abatement. A very different behavior occurs using the $\mathrm{BDD} / \mathrm{O}_{2}$ cell. Thus, anodic oxidation with BDD yields a slow, but continuous, TOC removal up to overall mineralization at $18 \mathrm{~A} \mathrm{~h} \mathrm{~L}^{-1}$. In contrast, electroFenton with BDD and $1 \mathrm{mM} \mathrm{Fe}^{2+}$ gives the quickest degradation until $6 \mathrm{~A} \mathrm{~h} \mathrm{~L} \mathrm{~L}^{-1}$, where TOC is reduced by $83 \%$, but at longer times the process becomes so slow that the 2,4-D solution is totally decontaminated after consumption of a specific charge similar to that of anodic oxidation with BDD. The higher degradation power of both methods with BDD can be accounted for the quicker production of - $\mathrm{OH}$ on its surface from reaction (1), accelerating the degradation of all organics up to their mineralization. Similar results were found for 4-CPA, MCPA and $2,4,5-\mathrm{T}$.

The TOC decay for the four herbicide solutions using both methods with BDD at $100 \mathrm{~mA}$ is presented in Fig. 9. A similar degradation rate can be seen for all solutions in each procedure, attaining their total mineralization after 6-8 $\mathrm{h}(6-8 \mathrm{~A}$ $\left.\mathrm{h} \mathrm{L}^{-1}\right)$ of electro-Fenton, a time slightly shorter than 9-10 $\mathrm{h}\left(9-10 \mathrm{~A} \mathrm{~h} \mathrm{~L}^{-1}\right)$ needed for anodic oxidation. Electro-Fenton with BDD can then mineralize completely all herbicide solutions at similar rate, even at low current. The degradation rate at the first stages (up to approximately $2 \mathrm{~h}$ ) of this method is very fast, but it needs practically the same time as anodic oxidation with BDD to yield total mineralization. This is due to the formation of hardly oxidizable products with - $\mathrm{OH}$, as complexes of $\mathrm{Fe}^{3+}$ with generated carboxylic acids, at the end of electroFenton. 


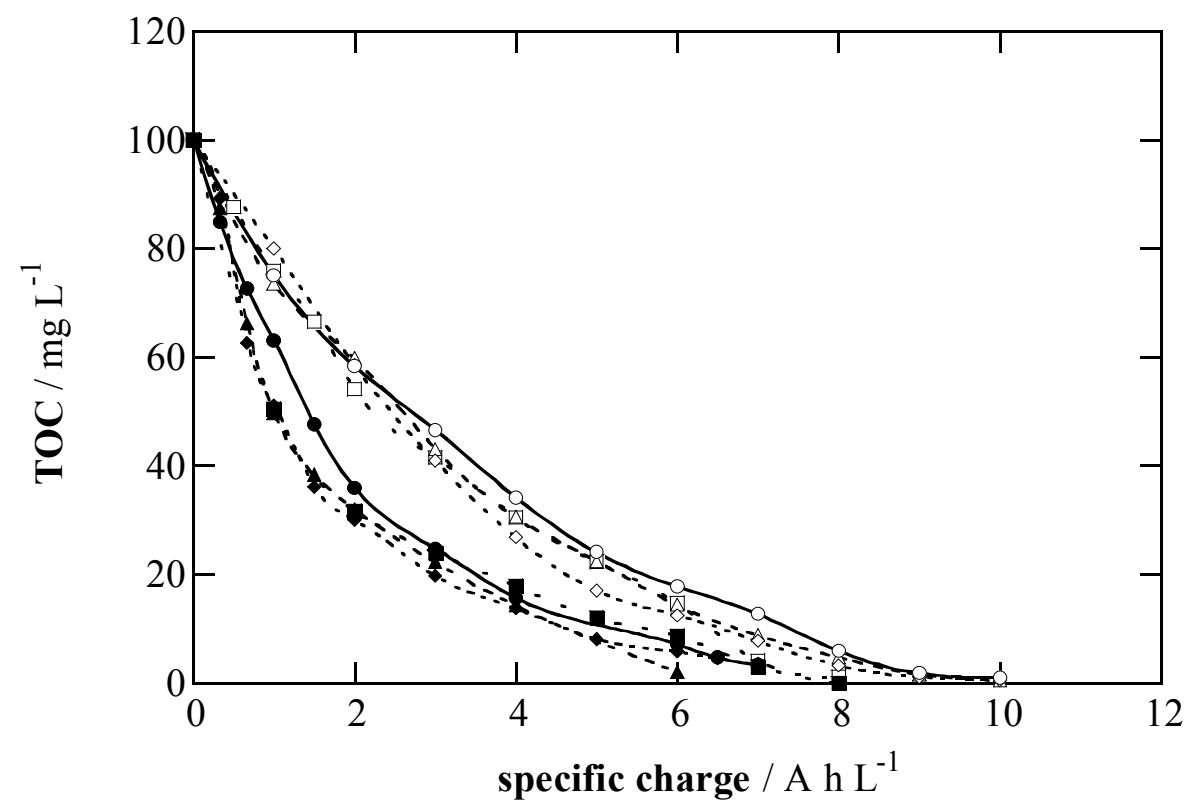

Figure 9. Variation of TOC removal with specific charge for the treatment of $100 \mathrm{~mL}$ of: $(O, \bullet) 194 \quad \mathrm{mg} \quad \mathrm{L}^{-1}$ 4-CPA, $(\square, \mathbf{\square}) 200 \quad \mathrm{mg} \quad \mathrm{L}^{-1}$ MCPA (4-chloro-2methylphenoxyacetic acid), $(\Delta, \boldsymbol{\Delta}) 230 \mathrm{mg} \mathrm{L}^{-1} 2,4-\mathrm{D},(\diamond, \diamond) 266 \mathrm{mg} \mathrm{L}^{-1} 2,4,5-\mathrm{T}(2,4,5-$ trichlorophenoxyacetic acid) solutions in $0.05 \mathrm{M} \mathrm{Na}_{2} \mathrm{SO}_{4}+\mathrm{H}_{2} \mathrm{SO}_{4}$ of pH 3.0 at $100 \mathrm{~mA}$ and at $35^{\circ} \mathrm{C}$ using a BDD/ $\mathrm{O}_{2}$ cell [33]. Method: $(\mathrm{O}, \square, \Delta, \diamond)$ anodic oxidation with BDD, $(\bullet, \boldsymbol{\square}, \boldsymbol{\Lambda}, \diamond)$ electro-Fenton with BDD and $1 \mathrm{mM} \mathrm{Fe}{ }^{2+}$.

The kinetics of the reaction of all herbicides with oxidants (mainly ${ }^{\bullet} \mathrm{OH}$ ) generated in the treatments with BDD at $100 \mathrm{~mA}$ was followed by reversedphase chromatography. The concentration-time plots thus obtained are depicted in Fig. 10(a) for anodic oxidation and Fig. 10(b) for electro-Fenton with $1 \mathrm{mM}$ $\mathrm{Fe}^{2+}$. In the first case, all compounds undergo a very slow decay up to their overall disappearance between $6 \mathrm{~h}$ for 2,4-D and $9 \mathrm{~h}$ for 2,4,5-T, a time slightly shorter than 9-10 h needed for their total TOC removal (see Fig. 9). This suggests the destruction of most oxidation products by ${ }^{\circ} \mathrm{OH}$ on the anode at the same rate as generated. In contrast, all herbicides are rapidly degraded by electro-Fenton, disappearing between $12 \mathrm{~min}$ for 2,4-D and $30 \mathrm{~min}$ for MCPA. The fastest decay of herbicides in electro-Fenton is due to their reaction with greater amounts of - $\mathrm{OH}$ produced in the medium from reaction (13). The kinetic analysis of the above results given in the inserts of Fig. 10(a) and 10(b) shows that all herbicides follow a pseudo first-order reaction.

Reversed-phase chromatography only allowed the detection of the primary phenol of each herbicide, that is, 4-chlorophenol for 4-CPA, 4-chloro-o-cresol for MCPA, 2,4-dichlorophenol for 2,4-D and 2,4,5-trichlorophenol for 2,4,5-T. Further aromatic products are more quickly destroyed by ${ }^{\circ} \mathrm{OH}$ at the anode surface and/or in the medium, leading to the release of $\mathrm{Cl}^{-}$, as stated above. Fig. 11(a) shows that the above phenols are continuously accumulated during the first 3-4 h of anodic oxidation and slowly destroyed at longer times, disappearing 
between $7 \mathrm{~h}$ for 2,4-dichlorophenol and $9 \mathrm{~h}$ for 4-chlorophenol, i.e., at similar times to those required for the removal of initial herbicides (see Fig. 10(a)). For electro-Fenton, Fig. 11(b) shows that 4-chlorophenol, 4-chloro-o-cresol, 2,4dichlorophenol and 2,4,5-trichlorophenol are quickly accumulated in less than 6 min and removed after 15-30 min of electrolysis, an analogous time to that needed for the complete decay of initial compounds (see Fig. 10(b)). Consequently, in both methods phenols are present in the medium while herbicides are destroyed.
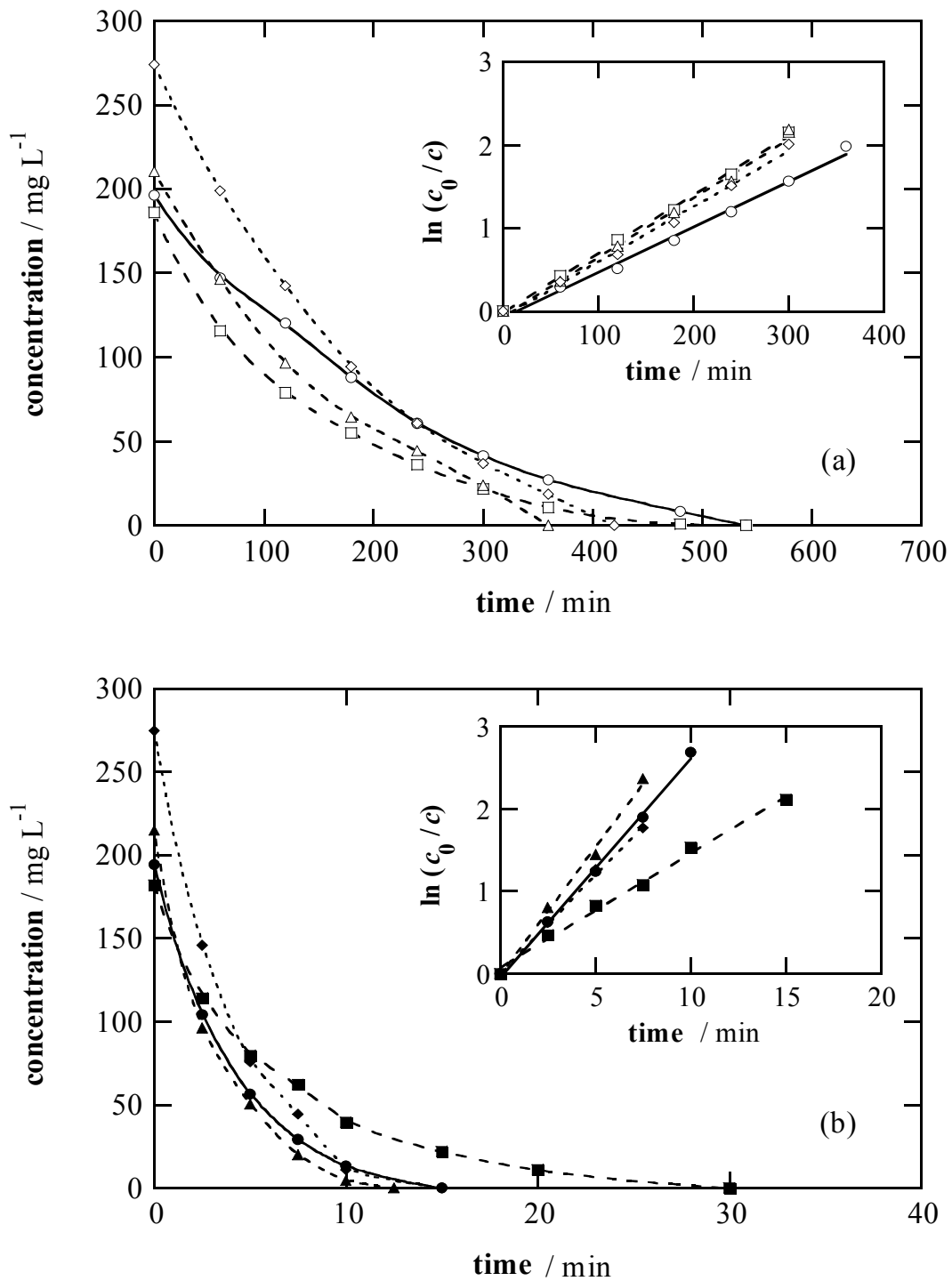

Figure 10. Concentration decay with electrolysis time during the degradation of 100 mL of: $(\mathrm{O}, \bullet) 194 \mathrm{mg} \mathrm{L}^{-1}$ 4-CPA, $(\square, \boldsymbol{\square}) 200 \mathrm{mg} \mathrm{L}^{-1} \mathrm{MCPA},(\Delta, \boldsymbol{\Delta}) 230 \mathrm{mg} \mathrm{L}^{-1}$ 2,4-D, $(\diamond, \diamond) 266 \mathrm{mg} \mathrm{L}^{-1} 2,4,5-\mathrm{T}$ solutions under the same conditions as in Fig. 9. Plot (a): anodic oxidation with BDD. Plot (b): electro-Fenton with BDD and $1 \mathrm{mM} \mathrm{Fe}{ }^{2+}$. The inset in each plot gives the corresponding kinetic analysis related to a pseudo first-order reaction for every compound. 

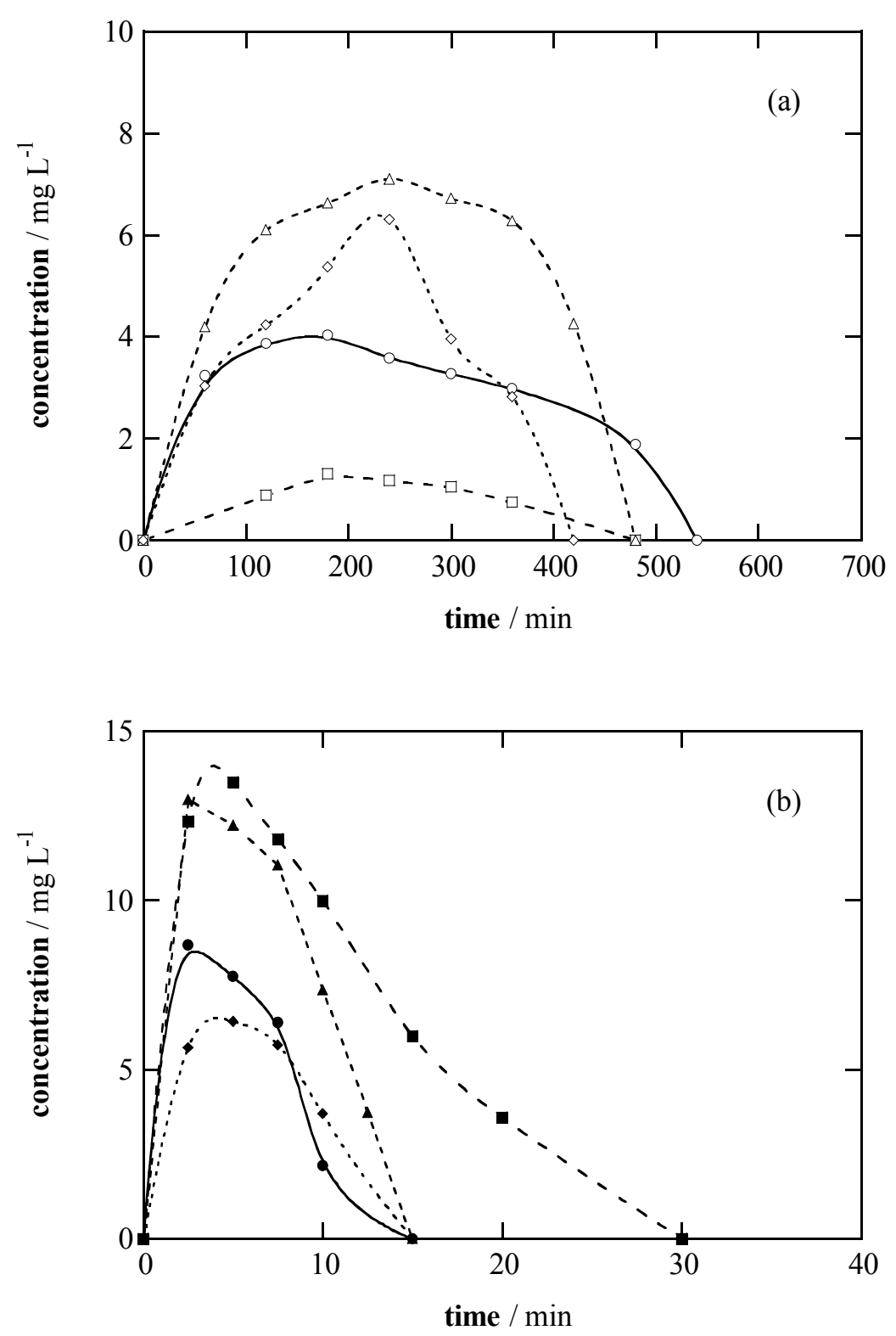

Figure 11. Time-course of the concentration of primary aromatic products during the degradation of solutions given in Fig. 9. $(\mathrm{O}, \bullet)$ 4-chlorophenol from 4-CPA, $(\square, \square)$ 4chloro-o-cresol from MCPA, $(\Delta, \boldsymbol{\Delta})$ 2,4-dichlorophenol from 2,4-D, $(\diamond, \diamond)$ 2,4,5trichlorophenol from 2,4,5-T. Plots correspond to: (a) anodic oxidation with BDD, (b) electro-Fenton with BDD and $1 \mathrm{mM} \mathrm{Fe}{ }^{2+}$.

Oxalic acid was detected as the ultimate carboxylic acid of the above-degraded solutions by ion-exclusion chromatography. Fig. 12 shows that its evolution depends on the method used for 4-CPA degradation. The concentration of oxalic acid in anodic oxidation grows to $16 \mathrm{mg} \mathrm{L}^{-1}$ during the first $2 \mathrm{~h}$ and further, it slowly decays up to its disappearance at $10 \mathrm{~h}$, just when 4-CPA (see Fig. 10(a)), 4-chlorophenol (see Fig. 11(a)) and the solution TOC (see Fig. 9) have been 
removed. In electro-Fenton this acid is accumulated in large extent during the first hour, up to $108 \mathrm{mg} \mathrm{L}^{-1}$, because of the fast degradation of aromatics and precedent carboxylic acids. At longer times, it is slowly transformed into $\mathrm{CO}_{2}$ until its removal at $8 \mathrm{~h}$, the same time as required for total 4-CPA mineralization (see Fig. 9). Similar results were found for the other herbicide solutions. The persistence of large amounts of oxalic acid in electro-Fenton with BDD can be ascribed to the formation of $\mathrm{Fe}^{3+}$-oxalato complexes [74], which can not be oxidized by ${ }^{\circ} \mathrm{OH}$ in the bulk solution since they are stable in electro-Fenton with $\mathrm{Pt}$ and hence, it can be concluded that they are mineralized by reaction with ${ }^{\bullet} \mathrm{OH}$ at the BDD surface. The very slow destruction of such complexes on BDD explains the difficulty of achieving total decontamination of herbicides by electro-Fenton. This occurs at similar times to those of their anodic oxidation treatments (see Fig. 9) in which oxalic acid is accumulated in low concentration (see Fig. 12) because it is practically removed at the same rate as produced.

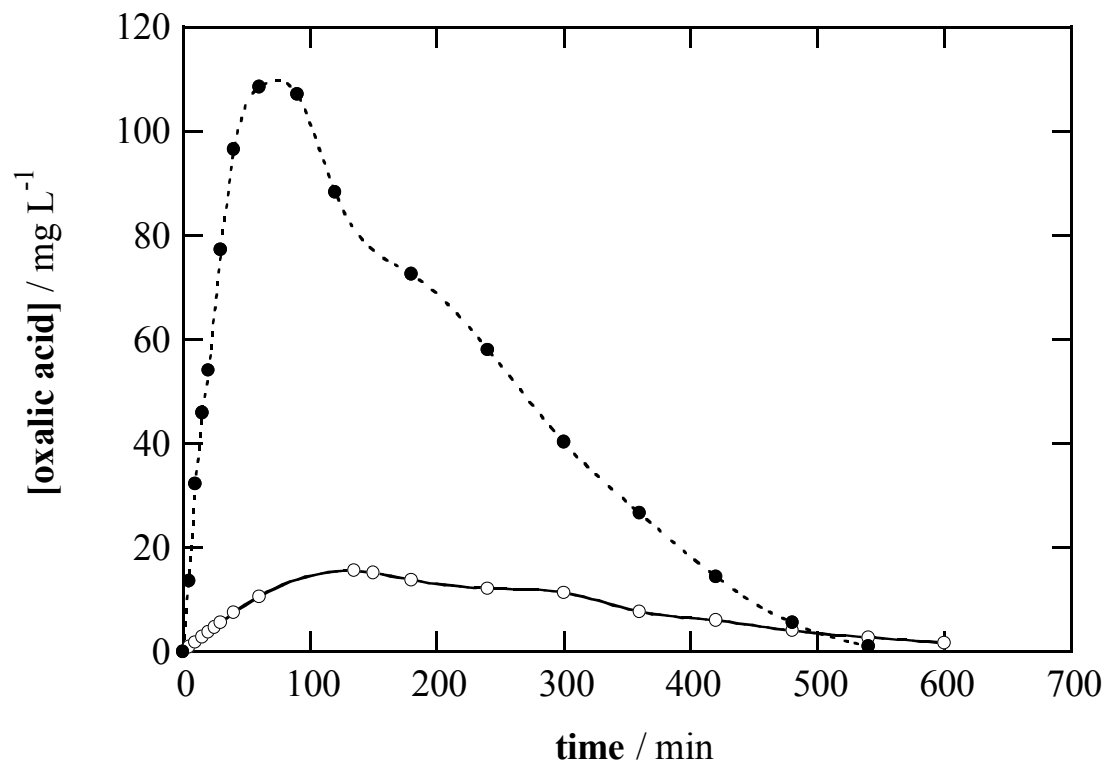

Figure 12. Evolution of oxalic acid concentration during the treatment of $194 \mathrm{mg} \mathrm{L}^{-1} 4$ CPA solutions under the same conditions as in Fig. 9. Method: $(O)$ anodic oxidation with BDD, (•) electro-Fenton with BDD and $1 \mathrm{mM} \mathrm{Fe}^{2+}$.

\section{AEOPs with an $\mathrm{Fe} / \mathrm{O}_{2}$ cell}

The degradation of acid solutions containing herbicides such as 4-CPA, MCPA, 2,4-D, 2,4,5-T and dicamba (3,6-dichloro-2-methoxybenzoic acid) were studied using an $\mathrm{Fe} / \mathrm{O}_{2}$ cell without (peroxi-coagulation process) and with UVA irradiation (photoperoxi-coagulation process) [57-60]. However, photoperoxicoagulation only led to a slightly faster TOC removal than peroxi-coagulation, indicating that UVA light is mainly absorbed by the $\mathrm{Fe}(\mathrm{OH})_{3}$ precipitate formed and by soluble $\mathrm{Fe}^{3+}$ to yield the photo-Fenton reaction (19), thus generating more oxidant ${ }^{\circ} \mathrm{OH}$ that accelerates the degradation process. For this reason, only the characteristics of peroxi-coagulation are presented herein. 


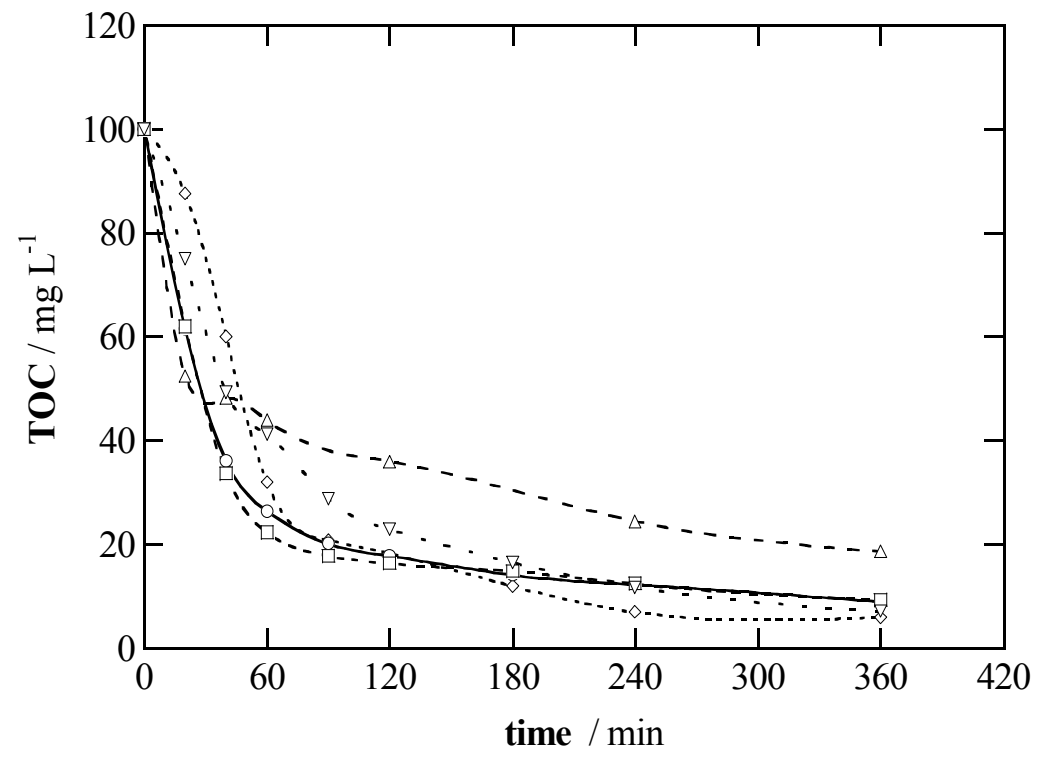

Figure 13. TOC abatement for the peroxi-coagulation degradation with an $\mathrm{Fe} / \mathrm{O}_{2}$ cell of

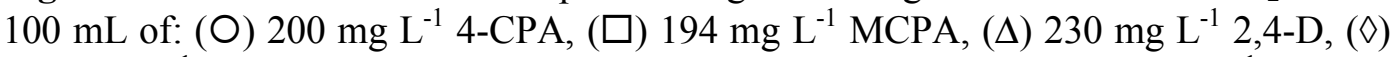
$230 \mathrm{mg} \mathrm{L}^{-1}$ dicamba (3,6-dichloro-2-methoxybenzoic acid), ( $\left.\nabla\right) 269 \mathrm{mg} \mathrm{L}^{-1}$ 2,4,5-T solutions in $0.05 \mathrm{M} \mathrm{Na}_{2} \mathrm{SO}_{4}+\mathrm{H}_{2} \mathrm{SO}_{4}$ of $\mathrm{pH} 3.0$, at $100 \mathrm{~mA}$ and at $35{ }^{\circ} \mathrm{C}$ under $\mathrm{pH}$ regulation [57].

Fig. 13 shows the TOC abatement found for different solutions of chlorophenoxyacetic and chlorobenzoic compounds of $\mathrm{pH} 3.0$ treated by peroxicoagulation at $100 \mathrm{~mA}$ under continuous $\mathrm{pH}$ regulation between 3.0 and 3.5 [57]. Under these conditions, the soluble TOC is quickly reduced during the two first hours until reaching about $80 \%$ of decontamination in all cases, except for $2,4-\mathrm{D}$ where TOC is only reduced by $62 \%$. At longer times, a much slower degradation occurs by the presence of hardly oxidizable products. The initial quickest destruction of soluble TOC can then be ascribed to the high production of oxidant ${ }^{\circ} \mathrm{OH}$ from reaction (13) by the continuous generation of $\mathrm{Fe}^{2+}$ from anode oxidation by reaction (22). This path also competes with coagulation of organic intermediates with the $\mathrm{Fe}(\mathrm{OH})_{3}$ precipitate formed, accelerating their disappearance from the medium. By increasing the current from 100 to $450 \mathrm{~mA}$, all herbicide solutions are more rapidly decontaminated due to the quicker production of $\mathrm{Fe}^{2+}$ and electrogenerated $\mathrm{H}_{2} \mathrm{O}_{2}$ (see Fig. 2).

At the end of the peroxi-coagulation treatment of each solution, the resulting $\mathrm{Fe}(\mathrm{OH})_{3}$ precipitate was collected by filtration, rinsed with pure water and dried until constant weight. Its overall $\mathrm{C}$ content was then determined by elemental analysis, thus allowing calculating the corresponding percentage of coagulated TOC. The percentage of mineralized TOC for each trial was further obtained as 
difference between its respective percentages of TOC removal and coagulated TOC. Table 1 collects these parameters for all herbicides after $6 \mathrm{~h}$ of peroxicoagulation at different currents. As can be seen, coagulation is an important degradation path at $100 \mathrm{~mA}$, being competitive with the mineralization one.

Table 1. Percentages of TOC removal and of coagulated and mineralized TOC obtained after $6 \mathrm{~h}$ of peroxi-coagulation treatments of $100 \mathrm{~mL}$ solutions of chlorophenoxyacetic and chlorobenzoic acids solutions with an herbicide concentration equivalent to $100 \mathrm{mg}$ $\mathrm{L}^{-1}$ of TOC in $0.05 \mathrm{M} \mathrm{Na}_{2} \mathrm{SO}_{4}+\mathrm{H}_{2} \mathrm{SO}_{4}$ of $\mathrm{pH} 3.0$ at $35{ }^{\circ} \mathrm{C}$ in an $\mathrm{Fe} / \mathrm{O}_{2}$ cell at different currents and under $\mathrm{pH}$ regulation [57].

\begin{tabular}{lcccc}
\hline & Current & \% TOC & \% coagulated & $\%$ mineralized \\
Herbicide & / mA & removal & TOC & TOC \\
\hline 4-CPA & 100 & 91 & 48 & 43 \\
MCPA & 100 & 92 & 49 & 43 \\
2,4-D & 100 & 81 & 38 & 43 \\
& 300 & 92 & 45 & 47 \\
& 450 & 92 & 50 & 42 \\
dicamba & 100 & 94 & 48 & 46 \\
& 300 & 94 & 94 & 0 \\
& 450 & 94 & 94 & 0 \\
\hline
\end{tabular}

However, coagulation predominates over mineralization as current applied increases. This trend can be easily deduced by the increase in coagulation from $38 \%$ at $100 \mathrm{~mA}$ to $50 \%$ at $450 \mathrm{~mA}$ for $2,4-\mathrm{D}$, although it is much more relevant for dicamba, where all organics removed $(94 \%)$ are retained by the $\mathrm{Fe}(\mathrm{OH})_{3}$ precipitate from $300 \mathrm{~mA}$, while they are partially mineralized at $100 \mathrm{~mA}$ with only $48 \%$ of coagulation. These results indicate that the production of more $\mathrm{Fe}(\mathrm{OH})_{3}$ precipitate with increasing current favors the coagulation of oxidation products of herbicides, thus avoiding their further mineralization.

On the other hand, the percentage of initial chlorine transformed into chloride ions after $6 \mathrm{~h}$ of electrolysis at $100 \mathrm{~mA}$ was found to be $86 \%$ for $4-\mathrm{CPA}, 76 \%$ for MCPA, $100 \%$ for 2,4-D and dicamba, and $90 \%$ for 2,4,5-T. This suggests that most chlorinated organics produced from the oxidation of herbicides during peroxi-coagulation are destroyed with loss of $\mathrm{Cl}^{-}$, whereas their resulting products are the species mainly retained in the $\mathrm{Fe}(\mathrm{OH})_{3}$ precipitate. 


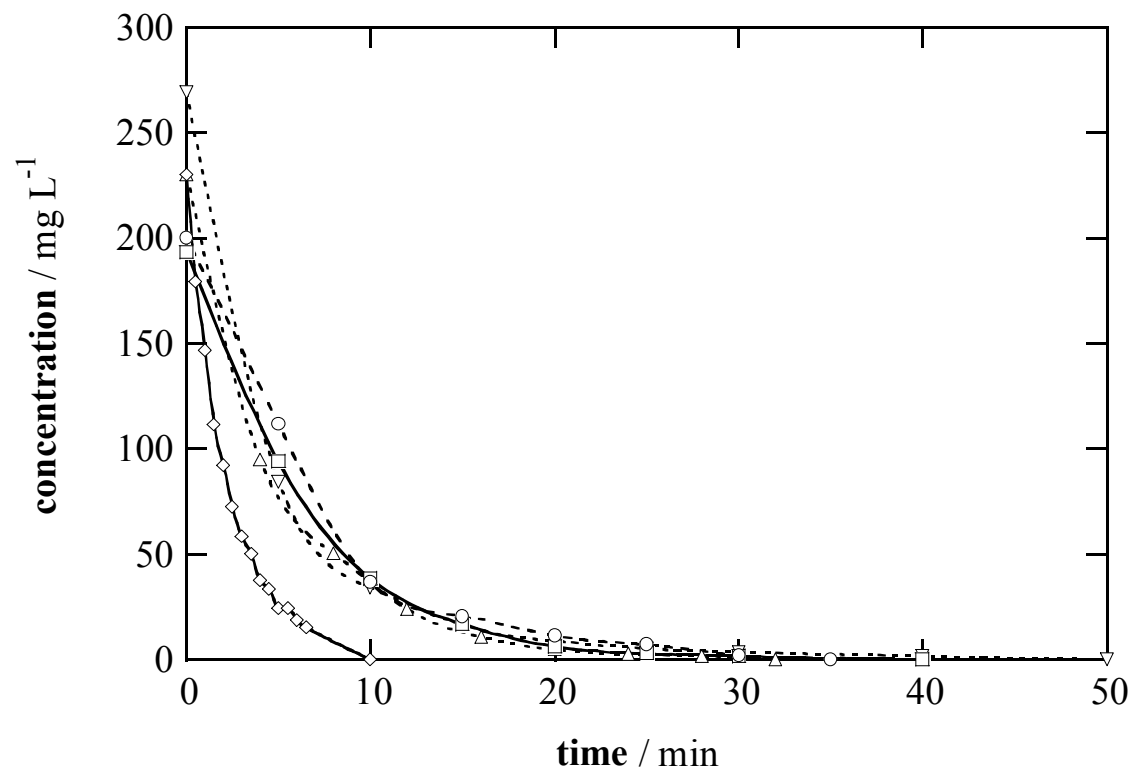

Figure 14. Time-course of the concentration of $(O)$ 4-CPA, $(\square) \mathrm{MCPA},(\Delta)$ 2,4-D, $(\diamond)$ dicamba, $(\nabla)$ 2,4,5-T under the same conditions as reported in Fig. 13.

Since no coagulation of herbicides with $\mathrm{Fe}(\mathrm{OH})_{3}$ occurs when their acid solutions are treated by electrocoagulation with an Fe/graphite cell without $\mathrm{H}_{2} \mathrm{O}_{2}$ electrogeneration [57], it can be inferred that they react with ${ }^{\circ} \mathrm{OH}$ in peroxicoagulation. The fast decay of these pollutants under these conditions, followed by reversed-phase chromatography, can be observed in Fig. 14. The four chlorophenoxy compounds are decomposed at similar rate, disappearing from the medium in ca. 30-40 min. For these compounds, an attack of ${ }^{\circ} \mathrm{OH}$ on the $\mathrm{C}(1)$ position of their rings occurs causing the breaking of the $\mathrm{C}(1)-\mathrm{O}$ bond to yield their phenol derivative and glycolic acid, as stated above. In contrast, the chlorobenzoic herbicide dicamba is more rapidly destroyed, since it is not detected in the solution from ca. $10 \mathrm{~min}$. Another kind of ${ }^{\circ} \mathrm{OH}$ reaction should then take place for dicamba, probably involving direct hydroxylation of its benzenic ring.

The existence of mineralization in peroxi-coagulation was confirmed by identifying and quantifying the organics formed in the degradation of herbicides by HPLC. The same products were found under these conditions as operating with the precedent AEOPs. As an example, Fig. 15 shows the evolution of selected products for a $190 \mathrm{mg} \mathrm{l}^{-1}$ MCPA solution of $\mathrm{pH} 3.0$ treated by peroxicoagulation at $100 \mathrm{~mA}[58]$. 

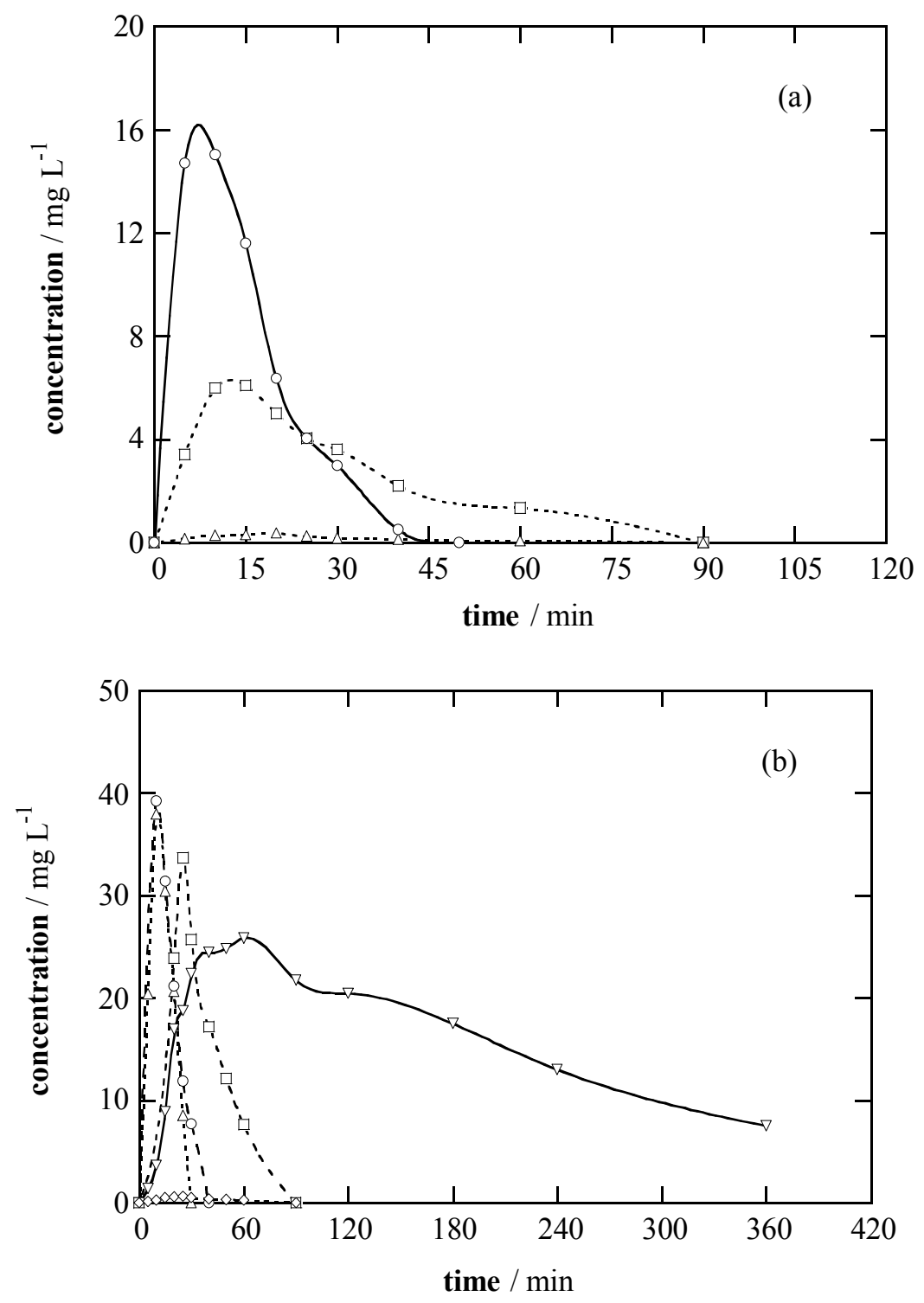

Figure 15. Evolution of the concentration of selected intermediates detected during the peroxi-coagulation process of a $190 \mathrm{mg} \mathrm{L}^{-1} \mathrm{MCPA}$ solution under the conditions given in Fig. 13 [58]. Plot (a): (O) 4-chloro-o-cresol, $(\square)$ methylhydroquinone, $(\Delta)$ methyl-pbenzoquinone. Plot (b): $(\bigcirc)$ glycolic acid, $(\square)$ formic acid, $(\Delta)$ malic acid, $(\diamond)$ maleic acid, $(\nabla)$ oxalic acid.

As can be seen in Fig. 15(a), the primary aromatic product 4-chloro-o-cresol is quickly formed, reaching its maximum concentration at $5-10 \mathrm{~min}$ and disappearing from the medium in $50 \mathrm{~min}$. Its derivatives methylhydroquinone and methyl-p-benzoquinone follow a similar trend, with maximum concentrations at approximately $15 \mathrm{~min}$ and remaining in the solution up to 90 min. Carboxylic acids such as glycolic, glyoxylic, formic, malic, maleic, fumaric and oxalic were also detected. Fig. 15(b) shows a fast formation and destruction of glycolic, formic, malic and maleic acids, disappearing in less than $90 \mathrm{~min}$. 
This behavior was also verified for fumaric and glyoxylic acids (not presented in Fig. 15(b)), but not for oxalic acid, which reaches its maximum concentration near $25 \mathrm{mg} \mathrm{L}^{-1}$ at $60 \mathrm{~min}$ and further, it is slowly destroyed to ca. $8 \mathrm{mg} \mathrm{L}^{-1}$ at $6 \mathrm{~h}$. This acid forms stable complexes with $\mathrm{Fe}^{3+}[74]$ that can be slowly removed by oxidation with ${ }^{\circ} \mathrm{OH}$ and/or coagulation with the $\mathrm{Fe}(\mathrm{OH})_{3}$ precipitate.

\section{Comparative degradation of chlorophenoxyacetic acid herbicides}

The oxidation power of each AEOP can be better explained from its apparent current efficiency (ACE), calculated for all trials from the following equation:

$$
\mathrm{ACE}=\left[\Delta(\mathrm{TOC})_{\text {exper }} / \Delta(\mathrm{TOC})_{\mathrm{theor}}\right] \times 100
$$

where $\Delta(\mathrm{TOC})_{\text {exper }}$ is the experimental TOC decay in solution at electrolysis time $t$ and $\Delta$ (TOC) $)_{\text {theor }}$ is the theoretically calculated TOC removal considering that the applied electrical charge ( $=$ current $\times$ time) is only consumed to give the corresponding mineralization reaction. For chlorophenoxyacetic acids, this overall process can be written as reaction (24) for 4-CPA, reaction (25) for MCPA, reaction (26) for 2,4-D and reaction (27) for 2,4,5-T, considering the formation of carbon dioxide and the release of chloride ions, as stated above.

$$
\begin{gathered}
\mathrm{C}_{8} \mathrm{H}_{7} \mathrm{ClO}_{3}+13 \mathrm{H}_{2} \mathrm{O} \rightarrow 8 \mathrm{CO}_{2}+\mathrm{Cl}^{-}+33 \mathrm{H}^{+}+32 \mathrm{e}^{-} \\
\mathrm{C}_{9} \mathrm{H}_{9} \mathrm{ClO}_{3}+15 \mathrm{H}_{2} \mathrm{O} \rightarrow 9 \mathrm{CO}_{2}+\mathrm{Cl}^{-}+39 \mathrm{H}^{+}+38 \mathrm{e}^{-} \\
\mathrm{C}_{8} \mathrm{H}_{6} \mathrm{Cl}_{2} \mathrm{O}_{3}+13 \mathrm{H}_{2} \mathrm{O} \rightarrow 8 \mathrm{CO}_{2}+2 \mathrm{Cl}^{-}+32 \mathrm{H}^{+}+30 \mathrm{e}^{-} \\
\mathrm{C}_{8} \mathrm{H}_{5} \mathrm{Cl}_{3} \mathrm{O}_{3}+13 \mathrm{H}_{2} \mathrm{O} \rightarrow 8 \mathrm{CO}_{2}+3 \mathrm{Cl}^{-}+31 \mathrm{H}^{+}+28 \mathrm{e}^{-}
\end{gathered}
$$

Although equation (23) can be strictly applied to the anodic oxidation, electroFenton and photoelectro-Fenton treatments of herbicides, where only mineralization takes place, it can also be utilized, as a first approach, to estimate the efficiency of their peroxi-coagulation process. ACE values thus calculated will be slightly higher than those expected if both coagulation and mineralization ways are involved, since in this case, lower number of electrons per mole of herbicide are consumed yielding greater $\Delta$ (TOC $)_{\text {theor }}$ values.

Selected percentages of TOC removal and their corresponding ACE values after $1 \mathrm{~h}$ and $3 \mathrm{~h}$ of electrolysis of chlorophenoxy herbicides at $\mathrm{pH} 3.0$ by different AEOPs at $100 \mathrm{~mA}$ are collected in Table 2. These results show that at aiven time, the oxidation ability of the mineralization treatments increases in the order: anodic oxidation with $\mathrm{Pt}<<$ anodic oxidation with $\mathrm{BDD} \leq$ electro-Fenton with $\mathrm{Pt}$ $<$ electro-Fenton with BDD $<$ photoelectro-Fenton with Pt. At $3 \mathrm{~h}$, for example, decontaminations of $12-19 \%$ for anodic oxidation with $\mathrm{Pt}, 54-59 \%$ for anodic oxidation with BDD, 53-66\% for electro-Fenton with $\mathrm{Pt}, 75-80 \%$ for electroFenton with BDD and $90-96 \%$ for photoelectro-Fenton with Pt, related to efficiencies of $3.1-6.0 \%, 15-18 \%, 14-20 \%, 21-24 \%$ and $25-29 \%$, respectively, are found. 
Table 2. Percentage of TOC removal, apparent current efficiency (ACE) and pseudo first-order rate constant determined for the degradation of $100 \mathrm{~mL}$ of chlorophenoxyacetic acid solutions with an herbicide concentration equivalent to 100 $\mathrm{mg} \mathrm{L}^{-1}$ of TOC in $0.05 \mathrm{M} \mathrm{Na}_{2} \mathrm{SO}_{4}+\mathrm{H}_{2} \mathrm{SO}_{4}$ of $\mathrm{pH} 3.0$ by different AEOPs at $100 \mathrm{~mA}$ [33,51,56-62].

\begin{tabular}{|c|c|c|c|c|c|c|c|}
\hline \multirow[b]{2}{*}{ Herbicide } & \multirow[b]{2}{*}{ Method $^{\mathrm{a}}$} & \multirow{2}{*}{$\begin{array}{c}T \\
/{ }^{\circ} \mathrm{C}\end{array}$} & \multicolumn{2}{|c|}{ after $1 \mathrm{~h}$ of treatment } & \multicolumn{2}{|c|}{ after $3 \mathrm{~h}$ of treatment } & \multirow{2}{*}{$\begin{array}{c}k \\
/ \min ^{-1}\end{array}$} \\
\hline & & & $\%$ TOC removal & $\overline{\mathrm{ACE}}$ & $\%$ TOC removal & $\overline{\mathrm{ACE}}$ & \\
\hline \multirow[t]{6}{*}{ 4-CPA } & $\mathrm{AO}-\mathrm{Pt}$ & 35 & 4.0 & 3.5 & 19 & 5.6 & $4.9 \times 10^{-3}$ \\
\hline & AO-BDD & & 25 & 22 & 54 & 16 & $5.4 \times 10^{-3}$ \\
\hline & EF-Pt & & 41 & 37 & 66 & 20 & 0.12 \\
\hline & EF-BDD & & 37 & 33 & 75 & 22 & 0.27 \\
\hline & PhEF-Pt & & 66 & 59 & 96 & 29 & 0.16 \\
\hline & Px & & 74 & 66 & 86 & 26 & 0.14 \\
\hline \multirow[t]{6}{*}{ MCPA } & $\mathrm{AO}-\mathrm{Pt}$ & 35 & 4.0 & 3.8 & 19 & 6.0 & $5.9 \times 10^{-3}$ \\
\hline & AO-BDD & & 24 & 23 & 58 & 18 & $7.0 \times 10^{-3}$ \\
\hline & EF-Pt & & 41 & 39 & 65 & 20 & 0.12 \\
\hline & EF-BDD & & 49 & 47 & 76 & 24 & 0.14 \\
\hline & PhEF-Pt & & 66 & 62 & 91 & 29 & 0.14 \\
\hline & Px & & 78 & 74 & 85 & 27 & 0.17 \\
\hline \multirow[t]{6}{*}{$2,4-\mathrm{D}$} & $\mathrm{AO}-\mathrm{Pt}$ & 25 & 4.7 & 3.9 & 13 & 3.6 & $7.9 \times 10^{-3}$ \\
\hline & AO-BDD & 35 & 27 & 22 & 57 & 16 & $7.1 \times 10^{-3}$ \\
\hline & EF-Pt & 25 & 35 & 29 & 57 & 16 & 0.18 \\
\hline & EF-BDD & 35 & 50 & 42 & 78 & 22 & 0.31 \\
\hline & PhEF-Pt & 25 & 52 & 44 & 90 & 25 & 0.23 \\
\hline & Px & & 56 & 47 & 76 & 21 & 0.19 \\
\hline \multirow[t]{6}{*}{$2,4,5-\mathrm{T}$} & $\mathrm{AO}-\mathrm{Pt}$ & 35 & 2.3 & 1.8 & 12 & 3.1 & $1.2 \times 10^{-2}$ \\
\hline & AO-BDD & & 20 & 16 & 59 & 15 & $6.6 \times 10^{-3}$ \\
\hline & EF-Pt & & 38 & 30 & 53 & 14 & 0.11 \\
\hline & EF-BDD & & 49 & 38 & 80 & 21 & 0.24 \\
\hline & PhEF-Pt & & 64 & 50 & 99 & 26 & 0.12 \\
\hline & Px & & 59 & 46 & 84 & 22 & 0.16 \\
\hline
\end{tabular}

${ }^{\text {a }} \mathrm{AO}-\mathrm{Pt}=$ anodic oxidation with a Pt/graphite cell, $\mathrm{AO}-\mathrm{BDD}=$ anodic oxidation with a $\mathrm{BDD} / \mathrm{O}_{2}$ cell, EF-Pt $=$ electro-Fenton with a $\mathrm{Pt} / \mathrm{O}_{2}$ cell and $1 \mathrm{mM} \mathrm{Fe}^{2+}, \mathrm{EF}-\mathrm{BDD}=$ electro-Fenton with a $\mathrm{BDD} / \mathrm{O}_{2}$ cell and $1 \mathrm{mM} \mathrm{Fe}{ }^{2+}, \mathrm{PhEF}-\mathrm{Pt}=$ photoelectro-Fenton with a $\mathrm{Pt} / \mathrm{O}_{2}$ cell, $1 \mathrm{mM} \mathrm{Fe}{ }^{2+}$ and UVA light, $\mathrm{Px}=$ peroxi-coagulation with an $\mathrm{Fe} / \mathrm{O}_{2}$ cell. 
The ACE values for all AEOPs, except for anodic oxidation with Pt, fall with increasing electrolysis time due to the presence of less pollutant in the solution. The same trend can be observed for peroxi-coagulation, which is usually the most effective method at $1 \mathrm{~h}$, although at $3 \mathrm{~h}$ it only attains a $76-86 \%$ of TOC decay with $21-27 \%$ of efficiency. The highest oxidation ability of photoelectroFenton with $\mathrm{Pt}$ at long electrolysis times can be related to the efficient photodecomposition of $\mathrm{Fe}^{3+}$-oxalate complexes that are difficulty destroyed by the greatest amounts of ${ }^{\bullet} \mathrm{OH}$ generated under peroxi-coagulation conditions.

The above results allow the conclusion that photoelectro-Fenton with $\mathrm{Pt}$ and electro-Fenton with BDD are very effective AEOPs for achieving the fast and total mineralization of acidic aqueous solutions contaminated with chlorophenoxyacetic acid herbicides. They are much more powerful than electroFenton with Pt, where very stable products are formed. Anodic oxidation with BDD has less oxidation power at short electrolysis time, although it permits overall decontamination at long times. Peroxi-coagulation also leads to a fast degradation of all herbicide solutions, with production of smaller amounts of difficulty oxidizable species. All these procedures become more efficient at short times. In contrast, anodic oxidation with $\mathrm{Pt}$ has so low oxidation ability to destroy such herbicides that is not useful in practice.

Another interesting parameter to clarify the action of the different AEOPs on the degradation of chlorophenoxy herbicides is the apparent pseudo first-order rate constant $(k)$ related to their reaction with ${ }^{\circ} \mathrm{OH}$, causing the breaking of the $\mathrm{C}(1)$ $\mathrm{O}$ bond to yield their phenol derivative and glycolic acid. As illustrated in the insert of Fig. 10(a) and 10(b), the kinetics of all herbicide decays in anodic oxidation with BDD and electro-Fenton with BDD follows a pseudo first-order reaction. The same behavior was found from kinetic analysis of their concentration decays by anodic oxidation with $\mathrm{Pt}$, electro-Fenton with $\mathrm{Pt}$, photoelectro-Fenton with $\mathrm{Pt}$ and peroxi-coagulation, presented in Fig. 5(c), 5(d) and 14. This suggests the production of a steady constant concentration of oxidant ${ }^{\circ} \mathrm{OH}$ in all cases. The $k$-value thus determined for all treatments is collected in the last column of Table 2. For anodic oxidation with $\mathrm{Pt}$, it ranges between $4.9 \times 10^{-3} \mathrm{~min}^{-1}$ for 4-CPA and $1.2 \times 10^{-2} \mathrm{~min}^{-1}$ for $2,4,5-\mathrm{T}$, values very similar to those found for anodic oxidation with BDD. This confirms that the greatest oxidation power of the last method is due to the ability of BDD to destroy generated carboxylic acids that are not degraded on Pt. Much higher $k$ values are obtained for the other AEOPs, where herbicides are mainly degraded by ${ }^{\bullet} \mathrm{OH}$ generated from Fenton's reaction (13). They vary between 0.11 and 0.31 $\min ^{-1}$, usually being higher for electro-Fenton with BDD. The similar $k$-values found for electro-Fenton and photoelectro-Fenton treatments with $\mathrm{Pt}$ discard direct photolysis of herbicides by UVA light.

\section{Final remarks}

AEOPs are powerful promising electrochemical methods for the degradation of organic pollutants in waters. They are environmentally friendly methods because 
of the use of oxidant species as ${ }^{\circ} \mathrm{OH}$ and $\mathrm{H}_{2} \mathrm{O}_{2}$ and can be applied with low salt contents in the medium. Iron ions acting as catalyst can be recovered by precipitation of their hydroxides at neutral $\mathrm{pH}$ and reused in further treatment of contaminated waters. All these methods are inexpensive and could be easily scaled-up to industrial applications. Anodic oxidation is only very effective using a BDD anode. Electro-Fenton with $\mathrm{Pt}$ has greater oxidation ability at short electrolysis times, but the formation of stable complexes with $\mathrm{Fe}^{3+}$ limits the degradation of aromatic pollutants. These products are completely oxidized in electro-Fenton with BDD or photodecomposed by the action of UVA light in photoelectro-Fenton with Pt. Peroxi-coagulation with Fe is also very effective, although coagulation of pollutants with the $\mathrm{Fe}(\mathrm{OH})_{3}$ precipitate formed usually predominates over their mineralization. The most efficient AEOP to destroy aromatics is photoelectro-Fenton, where solar irradiation could be used as UVA light source to reduce its operational cost.

\section{References}

1. J.J. Aaron, M.A. Oturan, Turk. J. Chem. 25 (2001) 509.

2. R. Andreozzi, V. Caprio, R. Marotta, D. Vogna, Wat. Res. 37 (2003) 992.

3. J.P. Bound, N. Vaulvaulis, Chemosphere 56 (2004) 1143.

4. M. Pera-Titus, V. García-Molina, M.A. Baños, J. Giménez, S. Esplugas, Appl. Catal. B: Environ. 47 (2004) 219.

5. J.F. Hunsberger, Standard Reduction Potentials, in: R.C. Weast (Ed.), Handbook of Chemistry and Physics, 58th ed., CRC Press, Ohio, 1977, pp. D141-144.

6. $\quad$ R.J. Bigda, Chem. Eng. Prog. 91 (1995) 62.

7. L. Kaba, G.D. Hitchens, J.O’M. Bockris, J. Electrochem. Soc. 137 (1990) 1341.

8. $\quad$ R. Kötz, S. Stucki, B. Carcer, J. Appl. Electrochem. 21 (1991) 14.

9. S. Stucki, R. Kötz, B. Carcer, W. Suter, J. Appl. Electrochem. 21 (1991) 99.

10. Ch. Comninellis, C. Pulgarin, J. Appl. Electrochem. 21 (1991) 703.

11. Ch. Comninellis, C. Pulgarin, J. Appl. Electrochem. 23 (1993) 108.

12. O.J. Murphy, G.D. Hitchens, L. Kaba, C.E. Verotsko, Wat. Res. 26 (1992) 443.

13. C. Seignez, C. Pulgarin, P. Peringer, Ch. Comninellis, E. Plattner, Swiss. Chem. 14 (1992) 25.

14. Ch. Comninellis, A. Nerini, J. Appl. Electrochem. 25 (1995) 23.

15. J. Feng, L.L. Houk, D.C. Johnson, S.N. Lowery, J.J. Carey, J. Electrochem. Soc. 142 (1995) 3626.

16. Ch. Comninellis, A. De Battisti, J. Chim. Phys. 93 (1996) 673.

17. L.L. Houk, S.K. Johnson, J. Feng, R.S. Houk, D.C. Johnson, J. Appl. Electrochem. 28 (1998) 1167.

18. S.K. Johnson, L.L. Houk, J. Feng, R.S. Houk, D.C. Johnson, Environ. Sci. Technol. 33 (1999) 2638.

19. E. Bonfatti, S. Ferro, F. Lavezzo, M. Malacarne, G. Lodi, A. de Battisti, J. Electrochem. Soc. 146 (1999) 2175. 
20. E. Bonfatti, S. Ferro, F. Lavezzo, M. Malacarne, G. Lodi, A. de Battisti, J. Electrochem. Soc. 174 (2000) 592.

21. G. Saracco, L. Solarino, R. Aigotti, V. Specchia, M. Maja, Electrochim. Acta 46 (2000) 373.

22. J.D. Rodgers, N.J. Bunce, Environ. Sci. Technol. 35 (2001) 406.

23. Z.C. Wu, M.H. Zhou, Environ. Sci. Technol. 35 (2001) 2698.

24. D. Gandini, E. Mahé, P.A. Michaud, W. Haenni, A. Perret, Ch. Comninellis, J. Appl. Electrochem. 30 (2000) 1345.

25. M.A. Rodrigo, P.A. Michaud, I. Duo, M. Panizza, G. Cerisola, Ch. Comninellis, J. Electrochem. Soc. 148 (2001) D60.

26. J. Iniesta, P.A. Michaud, M. Panizza, G. Cerisola, A. Aldaz, Ch. Comninellis, Electrochim. Acta 46 (2001) 3573.

27. F. Montilla, P.A. Michaud, E. Morallon, J.L. Vazquez, Ch. Comninellis, Electrochim. Acta 47 (2002) 3509.

28. B. Boye, P.A. Michaud, B. Marselli, M.M. Dieng, E. Brillas, Ch. Comninellis, New Diamond Frontier Carbon Technol. 12 (2002) 63.

29. P. Cañizares, M. Díaz, J.A. Domínguez, J. García-Gómez, M.A. Rodrigo, Ind. Eng. Chem. Res. 42 (2002) 4187.

30. A. Kraft, M. Stadelmann, M. Blaschke, J. Hazard. Mat. 103 (2003) 247.

31. S. Hattori, M. Doi, E. Takahashi, T. Kurosu, M. Nara, S. Nakamatsu, Y. Nishiki, T. Furuta, M. Iida, J. Appl. Electrochem. 33 (2003) 85.

32. P. Cañizares, J. García-Gómez, C. Sáez, M.A. Rodrigo, Ind. Eng. Chem. Res. 42 (2003) 956.

33. E. Brillas, B. Boye, I. Sirés, J.A. Garrido, R.M. Rodríguez, C. Arias, P.L. Cabot, Ch. Comninellis, Electrochim. Acta 49 (2004) 4487.

34. A.M. Polcaro, M. Mascia, S. Palmas, A. Vacca, Electrochim. Acta 49 (2004) 649.

35. M. Panizza, G. Cerisola, Electrochim. Acta 49 (2004) 3221.

36. P. Cañizares, C. Sáez, J. Lobato, M.A. Rodrigo, Ind. Eng. Chem. Res. 43 (2004) 1944.

37. C.A. Martinez-Huitle, S. Ferro, A. de Battisti, Electrochim. Acta 49 (2004) 4027.

38. P. Cañizares, C. Sáez, J. Lobato, M.A. Rodrigo, Electrochim. Acta 49 (2004) 4641.

39. C. Flox, J.A. Garrido, R.M. Rodríguez, F. Centellas, P.L. Cabot, C. Arias, E. Brillas, Electrochim. Acta 50 (2005) 3685.

40. E. Brillas, I. Sirés, C. Arias, P.L. Cabot, F. Centellas, R.M. Rodríguez, J.A. Garrido, Chemosphere 58 (2005) 399.

41. Y.L. Hsiao, K. Nobe, J. Appl. Electrochem. 23 (1993) 943.

42. J.S. Do, C.P. Chen, J. Electrochem. Soc. 140 (1993) 1632.

43. C. Ponce de Leon, D. Pletcher, J. Appl. Electrochem. 25 (1995) 307.

44 E. Brillas, E. Mur, J. Casado, J. Electrochem. Soc. 143 (1996) L49.

45. E. Brillas, E. Mur, R. Sauleda, L. Sánchez, J. Peral, X. Doménech, J. Casado, Appl. Catal. B: Environ.16 (1998) 31.

46. E. Brillas, R. Sauleda, J. Casado, J. Electrochem. Soc. 145 (1998) 759.

47. A. Alvarez-Gallegos, D. Pletcher, Electrochim. Acta 44 (1999) 2483. 
48. T. Harrington, D. Pletcher, J. Electrochem. Soc. 146 (1999) 2983.

49. M.A. Oturan, J.J. Aaron, N. Oturan, J. Pinson, Pestic. Sci. 55 (1999) 558.

50. D. Pletcher, Acta Chem. Scand. 53 (1999) 745.

51. E. Brillas, J.C. Calpe, J. Casado, Wat. Res. 34 (2000) 2253.

52. M.A. Oturan, J. Appl. Electrochem. 30 (2000) 475.

53. M.A. Oturan, N. Oturan, C. Lahitte, S. Trevin, J. Electroanal. Chem. 507 (2001) 96.

54. E. Brillas, J. Casado, Chemosphere 47 (2002) 241.

55. A. Ventura, G. Jacquet, A. Bermond, V. Camel, Wat. Res. 36 (2002) 3517.

56. B. Boye, M.M. Dieng, E. Brillas, Environ. Sci. Technol. 36 (2002) 3030.

57. E. Brillas, M.A. Baños, J.C. Calpe, B. Boye, J.A. Garrido, Chemosphere $51(2003) 227$.

58. B. Boye, E. Brillas, M.M. Dieng, J. Electroanal. Chem. 540 (2003) 25.

59. B. Boye, M.M. Dieng, E. Brillas, Electrochim. Acta 48 (2003) 781.

60. E. Brillas, B. Boye, M.M. Dieng, J. Electrochem. Soc. 150 (2003) E148.

61. E. Brillas, B. Boye, M.M. Dieng, J. Electrochem. Soc. 150 (2003) E583.

62. B. Boye, M.M. Dieng, E. Brillas, J. Electroanal. Chem. 557 (2003) 135.

63. B. Gözmen, M.A. Oturan, N. Oturan, O. Erbatur, Environ. Sci. Technol. 37 (2003) 3716.

64. E. Guivarch, N. Oturan, M.A. Oturan, Environ. Chem. Lett. 1 (2003)165.

65. I. Sirés, C. Arias, P.L. Cabot, F. Centellas, R.M. Rodríguez, J.A. Garrido, E. Brillas, Environ. Chem. 1 (2004) 26.

66. E. Brillas, M.A. Baños, S. Camps, C. Arias, P.L. Cabot, J.A. Garrido, R.M. Rodríguez, New J. Chem. 28 (2004) 314.

67. A. Wang, J. Qu, J. Ru, H. Liu, J. Ge, Dyes Pigments 65 (2005) 227.

68. A. da Pozzo, C. Merli, I. Sirés, J.A. Garrido, R.M. Rodríguez, E. Brillas, Environ. Chem. Lett. 3 (2005) 7.

69. J.J. Pignatello, Environ. Sci. Technol. 2 (1992) 944.

70. Y. Sun, J.J. Pignatello, Environ. Sci. Technol. 27 (1993) 304.

71. Y. Sun, J.J. Pignatello, J. Agric. Food Chem. 41 (1993) 308.

72. J. de Laat, H. Gallard, Environ. Sci. Technol. 33 (1999) 2726.

73. J.D. Rush, B.H.J. Bielski, J. Phys. Chem. 89 (1985) 5062.

74. Y. Zuo, J. Hoigné, Environ. Sci. Technol. 26 (1992) 1014.

75. $\quad$ D.A. Saltmiras, A.T. Lemley, Wat. Res. 36 (2002) 5113.

76. Q. Wang, T.A. Lemley, J. Environ. Qual. 33 (2004) 2343. 